\title{
Yükseköğretimde Eğitim-Öğretim Etiği Ölçeği-Öğrenci Formu: Geçerlilik ve Güvenirlik Çalışması ${ }^{1}$
}

\section{Özge Erdemli ${ }^{2} \quad$ Tuğba Güner Demir $^{3} \quad$ Gül Kurum ${ }^{4}$}

\section{Type/Tür:}

Research/Araştırma

Received/Geliş Tarihi: October

19/ 19 Ekim 2020

Accepted/Kabul Tarihi:

November 18/ 18 Kasim 2021

Page numbers/Sayfa No: $1392-$

1420

Corresponding

Author/İletişimden Sorumlu

Yazar:

ozge.erdemli8787@gmail.com

\section{$\checkmark$ iThenticate}

This paper was checked for plagiarism using iThenticate during the preview process and before publication. / Bu çalışma ön inceleme sürecinde ve yayımlanmadan önce iThenticate yazılımı ile taranmıştır.

Copyright (C) 2017 by Cumhuriyet University, Faculty of Education. All rights reserved.

\section{Öz}

Yükseköğretimde eğitim-öğretim etiğine ilişkin üniversite öğrencilerinin görüşlerini saptayan geçerli ve güvenilir bir ölçme aracı geliştirmeyi hedefleyen bu çalışma nicel araştırma yöntemiyle gerçekleştirilen bir ölçek geliştirme çalışmasıdır. Araştırma iki farklı çalışma grubuyla gerçekleştirilmiştir. Çalışma gruplarının belirlenmesinde amaçlı örnekleme yöntemlerinden ölçüt örneklem tekniğinden yararlanılmıştır. Birinci çalışma grubu 319 üniversite öğrencisinden oluşmaktadır. Bu çalışma grubundan toplanan veriler üzerinden açımlayıcı faktör analizi (AFA) ile güvenirlik analizleri yapılmıştır. AFA ile ölçeğin tek faktör ve beş bileşenden oluştuğu ve Cronbach Alpha katsayısına (.92) göre güvenilir olduğu tespit edilmiştir. İkinci çalışma grubu 315 üniversite öğrencisinden oluşmaktadır ve bu çalışma grubundan toplanan veriler doğrulayıcı faktör analizi (DFA) için kullanılmıştır. İkinci düzey DFA'dan elde edilen uyum indeksleri $\left(\chi^{2} / \mathrm{sd}=1.87\right.$, RMSEA $=.05, \mathrm{NFI}=.89, \mathrm{CFI}=.94, \mathrm{GFI}=.89, \mathrm{AGFI}=.86$, $\mathrm{CR}=.96)$ ölçeğin geçerli olduğunu göstermiştir. Araştırmadan elde edilen bulgular, geliştirilen ölçeğin yükseköğretimde eğitim öğretim etiğine yönelik öğrenci görüşlerini ölçmek için kullanılabilecek geçerli ve güvenilir bir araç olduğunu göstermektedir. Dolayısıyla bu ölçeğin, yükseköğretimde eğitim öğretim etiği ile ilgili araştırma yapmak isteyen araştırmacılar tarafından kullanılabileceği düşünülmektedir.

Anahtar Kelimeler: Etik, eğitim-öğretim etiği, yükseköğretim, ölçek geliştirme, geçerlik, güvenirlik.

\section{Suggested APA Citation/Önerilen APA Atıf Biçimi:}

Erdemli, Ö., Güner Demir, T., \& Kurum, G. (2021). Yükseköğretimde eğitim-öğretim etiği ölçeği-öğrenci formu: geçerlilik ve güvenirlik çalışması. Cumhuriyet International Journal of Education, 10(4), 1392-1420. http:/ / dx.doi.org/10.30703/cije.812337

\footnotetext{
${ }^{1}$ Bu çalışma 4. Uluslararası Yükseköğretim Çalışmaları Konferansı'nda sözlü bildiri olarak sunulmuştur.

2 Arş. Gör., Ankara Üniversitesi, Eğitim Bilimleri Fakültesi, Eğitim Yönetimi Bölümü, Ankara/Türkiye

Res. Assist., Ankara University, Faculty of Educational Sciences, Department of Educational Administration, Ankara/Turkey

e-mail: ozge.erdemli8787@gmail.com ORCID ID: orcid.org/0000-0002-8004-020X
}

${ }^{3}$ Arş. Gör., Ankara Üniversitesi, Eğitim Bilimleri Fakültesi, Eğitim Yönetimi Bölümü, Ankara/Türkiye Res. Assist., Ankara University, Faculty of Educational Sciences, Department of Educational Administration, Ankara/Turkey

e-mail: tugbaguner87@gmail.com ORCID ID: orcid.org/0000-0003-2653-2673

\footnotetext{
${ }^{4}$ Arş. Gör. Dr., Trakya Üniversitesi, Eğitim Fakültesi, Eğitim Yönetimi Bölümü, Edirne/Türkiye Res. Assist. Dr., Trakya University, Faculty of Education, Department of Educational Administration, Edirne/Turkey

e-mail: gulkurum@trakya.edu.tr ORCID ID: orcid.org/0000-0002-8686-7339
} 


\title{
Ethics in Higher Education Scale-Student Form: The Study of Validity and Reliability
}

\begin{abstract}
This study aims to develop a valid and reliable measurement tool, which determines the opinions of university students on ethics in education. It is a scale development study conducted with quantitative research methods. The research is carried out with two different study groups. Among purposeful sampling techniques, criterion sampling technique is used to determine the study groups. The first study group consists of 319 university students, and exploratory factor analysis (EFA) and reliability analysis are performed on the data collected from this study group. With EFA, it is determined that the scale consists of one factor and five components, and it is reliable according to Cronbach Alpha coefficient (.92). The second study group consists of 315 university students, and the data collected from this group are used for second level confirmatory factor analysis (CFA). The fit indices $\left(\chi^{2} / \mathrm{sd}=1.87, \mathrm{RMSEA}=.05, \mathrm{NFI}=.89, \mathrm{CFI}=.94\right.$, $\mathrm{GFI}=.89, \mathrm{AGFI}=.86, \mathrm{CR}=.96$ ) show that the scale is valid. The findings show that this scale is a valid and reliable tool that can be used to measure student views on ethics in higher education. Therefore, it is thought that researchers can conduct studies on ethics in higher education using this scale.
\end{abstract}

Keywords: Ethics, ethics in education, higher education, scale development, validity, reliability.

\section{Giriş}

Etik, bireylerin tutum ve davranışlarının iyi veya kötü, doğru ya da yanlış olarak incelenmesine rehberlik eden ilke, kural ve standartlar bütünü olarak ifade edilebilir (Aydın, 2016). Etik aslında eşitlik, adalet, özgürlük gibi evrensel ilkeler üzerine temellendirilmesine rağmen bu tanımdaki rol ve bağlam etiğin aynı zamanda hedef alınan örgüt ve üyelerine göre spesifik olabileceğini de vurgulamaktadır. Bu çalışmada etik, eğitim alanında ve yükseköğretim basamağında ele alınmıştır. Yükseköğretim kişilerin hizmet öncesi süreçte alanlarında uzmanlıklarını kazandıkları en üst düzey öğretim basamağıdır. Bu kapsamda üniversiteler öğrencilerini akademik açıdan geliştirmenin yanında ahlaki ve sosyal açıdan da gelişimlerini sağlamakla yükümlüdür. Eğitim hayatları boyunca öğrencilerle sürekli bir etkileşim içerisinde olan öğretim elemanları, öğrencilere rol model olmaları nedeniyle ayrı bir öneme sahiptirler. Bu sebeple öğretim elemanlarının yüklendikleri bu sorumluluğun farkında olarak eğitim öğretim sürecinde etik ilkelere uygun bir şekilde davranması büyük bir önem taşımaktadır.

Öğrenciler eğitim sisteminde yer alan önemli bir girdidir. Ayrıca yükseköğretim basamağındaki öğrenci kitlesi hizmet öncesi eğitimdeki bir yetişkin olarak eğitim-öğretim sürecini etik açıdan değerlendirip bazı çıkarımlarda bulunabilir. Diğer bir deyişle kişiler bu süreçte kendi mesleki değerlerini oluşturabilir. Bu sebeple öğretim elemanlarının ne öğrettiği ve nasıl öğrettiği kadar bu süreci bir bütün olarak tüm öğrencilere karşı nasıl yürüttüğü de önemsenmektedir. Alanyazında öğretim elemanlarının etik açıdan değerlendirildiği (Murray ve diğerleri, 1996; Morgan ve Korschgen, 2001; Kuther, 2003; Erdem ve diğerleri, 2014; Gedik Dinç ve Gizir, 2019; Yılmaz ve Ünsar, 2019) çeşitli çalışmalar yer almaktadır. Söz konusu çalışmalarda öğretim elemanlarının etik ve etik dışı davranışları genel bir bakış açısıyla öğrencilerin gözünden incelenmiştir. Nitel ve nicel yöntemlerle çeşitli ülkelerde yürütülen bu çalışmalar farklı fakülte ve seviyelerdeki öğrencilerle gerçekleştirilmiştir. Alanyazında 
yer alan çalışmalardan farklı olarak bu çalışmada olabildiğince kapsayıcı bir şekilde öğretim elemanlarının eğitim-öğretim sürecindeki davranışlarının öğrenciler tarafından etik açıdan değerlendirilmesine odaklanılmıştır. Bu çalışmada eğitimöğretim etiğinin kavramsallaştırılmasında Yükseköğretim Kurulu [YÖK] (2014) Etik Davranış İlkeleri temel alınmıştır.

Bireylerin nitelikli bir şekilde mezun olabilmelerinde onlara sunulan kaliteli bir lisans eğitiminin yanı sıra bu eğitim-öğretim sürecinde kişinin kazandığı etik davranış ve tutumların da etkisi olabilmektedir. Etik kavramı "insan davranışlarını doğruyanlış, iyi-kötü şeklinde sorgulayarak buna ilişkin bir değerlendirmede bulunmak" olarak tanımlanmaktadır (Arslan, 2014, s. 180). Diğer taraftan Cevizci (2002, s. 1) ise etik kavramını "belli bir yaşama idealini hayata geçirebilmek için mücadele eden, çağ1 ve üyesi olduğu toplumun yaşayışını eleştiren, hatta mahkûm eden, mevcut değerler silsilesi yerine alternatif değerleri koyan, yaşama kurallarını açık seçik tanımlayan, kısaca hayata anlam katan ahlaki ilkeler teorisi, felsefe disiplini" olarak ifade etmiştir. Bu bilgiler ışığında etik kavramının; insanın sergilediği davranış biçimlerini iyi-kötü ve doğru-yanlış şeklinde değerlendirilmesi olduğunu söylemek mümkündür.

Kişileri ahlaki açıdan değerlendiren, diğer insanların davranışlarını kınayan ya da öven herkesi ilgilendiren etik, eğitimde yadsınamaz bir yere sahiptir. Eğitimde etik, eğitimin hedefleri, değerleri ve süreçleri açısından öncelikle ele alınması gereken bir konudur. Eğitim insanı doğumundan ölümüne kadar etkileyen ve bireyde davranış değişikliği yaratmayı amaçlayan bir süreçtir. Etiğin insanoğlu için ne yapmalıyım? nasıl yaşamalıyım? gibi sorulara yanıt arayan bir kavram olduğu göz önüne alındığında eğitim ile etik arasında zorunlu bir ilişki olduğunu söylemek mümkündür. Diğer bir deyişle eğitim, yaşam boyu süren "etik olarak kişinin kendini tanıma sürecidir"'(Aydın, 2006).

Eğitim etiği uygulamalı etik dallarından biridir. Eğitim ile etik ilişkisi bir bütün olarak eğitme otoritesinin diğer bir deyişle öğretmen ya da öğretim elemanının yükümlülüğü veya sorumluluğu noktasında temellendirilmiştir. Bu kapsamda eğitim kendi içinde iyi bir şey olup asli bir değer taşımaktadır. İnsan eğitim sayesinde daha iyi ve daha bilgili hale gelmektedir. Diğer taraftan eğitim sosyo-politik yapılara ve dünya çapındaki gelişmelere göre yapılandırılmaktadır. Bu doğrultuda etik ile eğitim ilişkisini amaçlar üzerinden de temellendirmek mümkündür. Çünkü eğitsel amaçlar ulaşılmak istenen insan profilini yansıtmaktadır (Cevizci, 2016, ss. 257-258). Görüldüğü üzere bu kadar önemli bir sürecin etik açıdan iyi ve doğru şekilde yürütülmesi için eğitim-öğretim etiğine gerek duyulduğunu söylemek mümkündür.

Eğitim ve öğretimde etik konular geniş kapsamlı, çok yönlü ve değer sistemlerinin gözden geçirilmesini gerektiren bir niteliğe sahiptir. Eğitimciler, her öğrencinin toplumun değerli ve etkili bir üyesi olarak kendi potansiyelini fark etmesine yardımcı olmaya çalışmaktadır (Strike ve Soltis, 2009). Diğer bir deyişle yönetici ve öğretmenler birçok ahlaki sorunla uğraşmalarının dışında gelecek kuşağın nitelikli bir eğitim almasında ve ahlaki açıdan iyiliğinde çok daha fazla sorumluluk almaktadırlar (Haynes, 2002). Dolayısıyla etik ilkeleri benimsemiş ve yaşantısında bunu sergileyen eğitimciler gelecek kuşak için anahtar bir rol oynamaktadır.

Öğretim yapmak ya da öğretmenlik hangi okul kademesinde olursa olsun toplumun hizmetine koşulmuş, profesyonellik gerektiren bir meslektir. Bu doğrultuda öğrencilere etkili bir eğitim-öğretim hizmeti verebilmek belirli kod, ilke, kural ve standartları gerektirmektedir. Bu kurallar bütünü eğitim-öğretim etiği ilkeleri olarak 
belirlenmiştir. Bu kapsamda uygulamacı olarak öğretmen ya da öğretim elemanlarının öğrencilerine kendi kişisel amaçlarının bir aracı olarak değil, bir amaç olarak davranması beklenmektedir. Çünkü her insan en yüksek değere sahip bir amaç olup, en yüksek saygıya layıktır. Bu bağlamda öğretmenlerin konularını olabilecek en iyi şekilde ve mutlak doğruluk içinde öğretmesi, sınıf ortamını demokratik ilke ve değerlere uygun şekilde yönetmesi ve etkili bir öğrenme atmosferi yaratması gerekmektedir (Cevizci, 2019, ss. 296-300). Bu temel değerlere de ancak eğitim-öğretim etiği ilkelerine uygun davranarak ulaşılabileceğini söylemek mümkündür.

Öğretim elemanları/akademisyenler üniversitelerin temel yapı taşlarıdır (Ay, 2017). Bir öğretim elemanın, üniversitelerin amaçlarına yönelik olarak meslek insanı yetiştirme (eğitim-öğretim), bilimsel araştırma yapma ve topluma hizmet sunma gibi çeşitli sorumlulukları bulunmaktadır (Aypay, 2006). Akademisyenlerin farklı bilim dallarında hem teorik hem de uygulamalı bu faaliyetleri gerçekleştirirken mesleki etik ilkeler bütününü oluşturmaları önemli ve gerekli görülmektedir. Çünkü üniversite sadece etik değerleri öğreten bir yer olmanın ötesinde aynı zamanda etik bir kurum olarak algılandığı için etik açıdan önemli bir role sahiptir (Aydın, 2016). Akademisyenlerin söz edilen sorumlulukları arasında en önemlilerinden bir tanesi öğretim faaliyetidir (Gedik Dinç ve Gizir, 2019). Dolayısıyla öğretim elemanlarının tıpkı bilimsel araştırma sürecinde olduğu gibi öğretim faaliyetini yerine getirirken de mesleki ilkeler bütününe göre hareket etmesi oldukça önemlidir.

Üniversite öğretim elemanları genellikle öğrencileri profesyonel yaşamın taleplerine göre hazırlamaktadır. $\mathrm{Bu}$ geleceğin doktorlarının, hemşirelerinin, mühendislerinin, mimarlarının, avukatlarının ve öğretmenlerinin eğitimini içermektedir (Macfarlane, 2004). Şüphesiz ki öğretim elemanlarının bu eğitim esnasında sergilediği etik davranış ve tutumlar, bu değerlerin geleceğin meslek üyelerine aktarılması açısından da önem taşımaktadır.

Brown ve Krager, (1985) yükseköğrenimin topluma karşı etik yükümlülüklerini yerine getirmesi gerekiyorsa, en mantıklı başlangıç yerinin öğretim elemanları ile öğrenciler arasındaki etkileşim olduğunu belirtmektedir. Çünkü yükseköğretimde dersler, öğretim elemanlarına muazzam bir güç veren ve bununla birlikte öğrencilere nefes almaları ve kendi eleştirel seslerini geliştirmeleri için alan tanıma görevini de beraberinde getiren bir platformdur (Macfarlane, 2004). Ancak öğretim sürecinde öğrenci ve öğretim elemanları arasındaki ikili ilişki birçok etik riske sahiptir. Bu sebeple öğretim elemanları öğrencilere karşı etik davranma konusunda profesyonel sorumluluğa sahiptir (Blevins-Knabe, 1992).

Üniversiteler ilk bakışta en yüksek etik ideallerin bulunduğu ve rutin olarak uygulandığı yerler arasında görülebilir. Ancak, yükseköğretim kurumlarında etik çatışmaların yaşanması potansiyeli her zaman mevcuttur (Keith-Spiegel, Whitley, Balogh, Perkins ve Wittig, 2002). Yükseköğretim basamağı özel bir eğitim bağlamı olarak hem olumlu hem de olumsuz açılardan dikkatleri üzerine çeken bir yapı taşımaktadır. Olumlu olarak yükseköğretim kendine has özerk yapısı ile ifade, eğitim programı tasarımı, öğretim yöntemleri ve araştırma gibi alanlarda büyük ayrıcalıklarla ilişkilendirilmektedir (Macfarlane, 2004). Olumsuz olarak ise yükseköğretim kurumları sıklıkla idari (kayırmacılık, nepotizm, üniversite malının kötüye kullanımı ve vergilerde hile yapmak gibi), akademik ve mesleki (kabul, notlandırma/değerlendirme, akademik ürünlerde intihal, ihmal ve istismar gibi) alanlarda suistimal ve yozlaşma konusunda sıklıkla gündeme gelmektedir 
(Heyneman, 2011). Bu doğrultuda yükseköğretimdeki idari ve akademik işleyişte görev alan öğretim elemanlarının hak, görev, rol ve sorumlulukları ve bunları nasıl yerine getirdikleri uzun süredir üzerinde tartışılan bir konudur.

Yükseköğretimde sınıfın içinde olup bitenler, bazı yazar ve politikacılar tarafından "gizli bir bahçeye" benzetilmektedir (Macfarlane, 2004). Dolayısıyla bu gizli bahçede uyulması gereken etik kodları belirlemek belli davranış standartlarını sağlamak açısından önem taşımaktadır. Üniversite öğretiminde etik, hayatın her alanında olduğu gibi, karmaşık bir iştir. Bu nedenle etik, doğru ve yanlışı dikte eden basit bir çözüm kontrol listesine indirgenmemelidir (Macfarlane, 2004). Ancak bu ilkeler etik davranışı garanti etmese de süreç bireylerin kültürel olarak benzer bir dili konuşmaları ve bu tür bir performans için çabalamaları için bilişsel bir kabul yaratır (Clevenger, 2019). Eğitimciler için oluşturulan etik kodlar, tüm eğitimcilere davranışlarını sorgulamak için standartlar sağlamaktadır (Strike ve Soltis, 2009). Bir öğretim elemanının eğitim öğretim etiği kapsamında sağlaması gereken en önemli ilke "yeterliliktir". Öğretim elemanları alanlarında yeterli olmalıdırlar. Ayrıca akademik bilginin yayılmasında temel araçlardan birinin eğitim öğretim olduğu göz önüne alındığında öğretim elemanlarının sahip olacağı öğretim ilke ve yöntemleri/öğretim becerileri oldukça önemli bir yere sahip olmaktadır (Aydın, 2016). Ancak tek başına öğretim elemanının akademik bilgi ve becerisi etkili bir eğitim-öğretim süreci için yeterli değildir. $\mathrm{Bu}$ yeterliğin etik ilkeler doğrultusunda öğrencilere sunulması gerekmektedir. Bu kapsamda Strike ve Soltis (2009) eğitimcilerin öğrencilere yönelik etik davranış ilkelerini şöyle sıralamaktadır: Eğitimciler;

1. Öğrenciyi, öğrenme sürecinde geçerli bir sebep olmaksızın bağımsız eylemde bulunmaktan alıkoymamalıdır.

2. Öğrencinin farklı bakış açılarına erişimini keyfi olarak engellememelidir.

3. Öğrencinin ilerlemesiyle ilgili kaynakları kasıtlı olarak gizli tutmamalı veya çarpitmamalıdır.

4. Ö ğrenciyi eğitim, sağlık ve güvenliğine zarar verecek koşullardan korumak için gerekli çabayı göstermelidir.

5. Ö ğrenciyi kasıtlı olarak utandırmamalı veya küçük düşürmemelidir.

6. Irk, renk, mezhep, cinsiyet, ulusal köken, medeni durum, siyasi veya dini inanç, aile, sosyal veya kültürel geçmiş veya cinsel yönelim temelinde haksız yere

a. Herhangi bir öğrenciyi herhangi bir programa katılmaktan men etmemelidir;

b. Herhangi bir öğrenciye fayda sağlamaya karşı olmamalıdır;

c. İhtiyaç sahibi herhangi bir öğrenciye yardım edebilmelidir.

7. Öğrencilerle olan mesleki ilişkilerini özel menfaatleri için kullanmamalıdır.

8. Akademik bir amaç ya da yasalar tarafından zorunda bırakılmadıkça, danışmanlık kapsamında elde edilen öğrenciye ait kişisel bilgileri ifşa etmemelidir.

Görüldüğü gibi bir eğitimcinin öğrencilere karşı gerçekleştirmesi gereken çeşitli etik sorumlulukları bulunmaktadır. Bir öğretmen olarak üniversitede görev yapan öğretim elemanlarının mesleki sorumluluklarını tanımlayan Murray ve diğerleri (1996) ise bir dizi temel etik ilkeyi belirlemiştir. Bu ilkeler yazarlar tarafından şu şekilde belirtilmektedir: 
1. Yeterlilik: Bir üniversitenin öğretim elemanı yüksek düzeyde konu bilgisine sahiptir ve ders içeriğinin güncel, doğru, özgün ve öğrencinin öğrenim programı içindeki dersin hedefine uygun olmasını sağlar.

2. Pedagojik yeterlilik: Pedagojik olarak yetkin bir öğretim elemanı, dersin amaçlarını öğrencilere iletir, alternatif öğretim yöntemlerinin veya stratejilerinin farkındadır ve araştırma kanıtlarına göre (kişisel veya kendini yansıtan araştırmalar dahil) öğrencilerin ders hedeflerine ulaşmalarında etkili olan öğretim yöntemlerini seçer.

3. Hassas konulara özen gösterme: Öğrencilerin hassas veya rahatsız edici bulması muhtemel konular açık, dürüst ve olumlu bir şekilde ele alınır.

4. Öğrenci gelişimi: Öğretim elemanının en önemli sorumluluğu, en azından kendi uzmanlık alanı bağlamında, öğrencinin entelektüel gelişimine katkıda bulunmak ve öğrenci gelişimini engelleyen sömürü ve ayrımcılık gibi eylemlerden kaçınmaktır.

5. Öğrencilerle ikili ilişkiler: Çıkar çatışmasından kaçınmak için, öğretim elemanı öğrenci gelişiminden uzaklaşması muhtemel ya da gerçek veya algılanan kayırmaya yol açması olası öğrencilerle ikili rol ilişkilerine girmez.

6. Gizlilik: Öğrenci notları, devam kayıtları ve özel iletişim bilgileri gizli materyaller olarak ele alınır ve yalnızca öğrenci rızasıyla, yasal akademik amaçlarla veya bu tür bilgilerin serbest bırakılmasının öğrenciye faydalı olacağına veya zarar görmesini engelleyeceğine dair makul gerekçeler varsa paylaşılır.

7. Meslektaşlara saygı: Bir öğretim elemanı meslektaşlarının onuruna saygı duyar ve öğrenci gelişimini teşvik etmek için meslektaşları ile işbirliği içinde çalışır.

8. Öğrencilerin değerlendirilmesi: Üniversite öğretiminde, öğrencilerin yaşamlarında ve kariyerlerinde öğrenci performansının değerlendirilmesinin önemi göz önüne alındığında, eğitmenler, öğrencilerin değerlendirmesinin geçerli, açık, adil ve ders hedeflerine uygun olmasını sağlamak için gerekli adımları atmaktan sorumludur.

9. Kuruma sayg1: Öğrenci gelişimi yararına bir öğretim elemanı, çalıştığ1 kurumun eğitim hedefleri, politikaları ve standartlarının farkındadır ve bunlara sayg1 duyar.

Görüldüğü üzere Murray ve diğerleri (1996) üniversitede öğretim elemanlarının eğitim-öğretim faaliyetlerini yerine getirirken uymaları gereken etik ilkeleri dokuz temel alanda değerlendirmiştir. Akademi topluluğu için etik kuralları uyarlayan Keith-Spiegel ve diğerleri (2002) ise etik ilkeleri sekiz maddede özetlemektedir. Bu ilkeler;

1. Başkalarının özerkliğine sayg1: Öğrencilerin, öğretim görevlilerinin ve personelin eylemleri başkalarının haklarına ve refahına müdahale etmediği sürece onların yaşamda kendi yollarını seçme haklarını kabul etmek; fikirlerin özgürce ifade edilmesine değer vermek ve fikirlere karşı uygun, şiddetsiz tepki vermek; kendi görüşlerini dikte etmek yerine akademik gelişim düzeylerine uygun öğrenci keşfini teşvik etmek; öğrenmeye elverişli rahat bir ortam sağlamak.

2. Zarar vermemek: Öğrenciler ve meslektaşları ile istismarcı olmayan ilişkiler kurmak; kötü karar/yarg1 ile sonuçlanabilecek etik veya kişisel sorunlar ortaya çıktığında danışmaya istekli olmak; işteki önyargının zararlı etkilerini bilinçli ve aktif 
bir şekilde ortadan kaldırmaya çalışmak; meslektaşların ve öğrencilerin pasif olarak etik olmayan davranışlarına tolerans göstermeyi reddetmek.

3. Başkalarına fayda sağlamak: Öğrenci refahı ve gelişimi için sorumluluğu kabul etmek; kendi yetkinliğini korumak; bilinçli bir şekilde, öğretim ve danışmanlığın yürütülmesinde güvenilir performans gibi öğrencilerin hakkı olan hizmetleri sunmak; rollerinin model ve örnek olduğunu kabul etmek.

4. Adalet ve eşitlik: Başkalarına benzer koşullar altında muamele görmek istediğin gibi davranmak; öğrencileri, personeli ve akranları değerlendirirken adil uygulamaları ve objektifliği sürdürmek.

5. Sadakat ve dürüstlük: Öğrenciler, personel ve meslektaşlarla ilişkilerde sadakat, doğruluk, dürüstlük ve sözünü tutma ilkelerine göre davranmak, öğretmenlik mesleğine başkalarının güvenini azaltacak davranışlardan kaçınmak; öğrencilerle ilişkilerde açıklık sergilemek ve uygun olduğunda bilgilendirilmiş onay prosedürlerini kullanmak.

6. Saygınlık: Öğrencilere, personele ve meslektaşlara itibar göstermek, kibir ve uygunsuz duygu gösterilerinden kaçınmak; çeşitliliğe saygı duymak.

7. Önemseme: Profesyonel ve kurumsal görevleri özenle yerine getirmek; şefkati öğrencilere, personele ve akranlarına mümkün olan en geniş ölçüde yaymak.

8. Elinden gelenin en iyisini yapmak: mükemmellik arayışına değer vermek; işinden gurur duymak.

Buraya kadar tartışılan ilkeler incelendiğinde üniversitede öğretim elemanlarının bir eğitimci olarak zarar vermeme, adalet ve eşitlik, ayrımcılık yapmamak, çıkar çatışmasından kaçınmak, gizlilik ve mahremiyet, saygı, yeterlilik, sadakat ve dürüstlük gibi birçok etik ilkeye göre hareket etmesi gerekmektedir. Türkiye'de de YÖK, yayımladığı yükseköğretim kurumları etik davranış ilkeleri rehberinde öğretim elemanlarının etik yükümlülüklerini belirlemiştir. Bu rehberde bilimsel araştırma, yayın ve değerlendirme etiği, eğitim-öğretim etiği, hizmet etiği ve akademik yönetim etiği gibi alanlarda etik ilkeler belirlenmiştir. Ĕ̆itim-öğretim etiği doğrultusunda öğretim elemanları program içeriğine uygun bir şekilde derslerini yerinde ve zamanında yapmakla, ders planı hazırlamakla, özel gereksinimli öğrencilerin ihtiyaç duyduğu yardım ve desteği sunmakla ve öğrenci notlarını ilgili sistemde uygun bir şekilde açıklamakla yükümlüdür (YÖK, 2014). Başka bir ifade ile eğitim-öğretim süreci öğretim elemanlarının mazeret veya izin durumu haricinde ders planına uygun olarak yürütülmelidir. Bu doğrultuda hem uluslararası etik kurallar (örn. Cambridge Üniversitesi, 2011; Harvard Üniversitesi, 2020) hem de ulusal etik davranış ilkeleri (YÖK, 2014) yükseköğretim kurumlarının eğitim-öğretim sürecini sağlıklı ve doğru bir şekilde yürütmesi amacıyla paydaşlara rehberlik etmektedir.

Uluslararası ve ulusal alanyazında yükseköğretimde eğitim-öğretim etiğine ilişkin görüşleri ve algıları belirlemeye yönelik çeşitli ölçme araçlarına rastlanmaktadır. Schnake, Fredenberger ve Dumler (2004) tarafından geliştirilen, Özcan ve Balyer (2012) tarafından Türkçe'ye uyarlanan Öğretim Elemanlarının Etik Davranışları Ölçeği, öğretim elemanlarının ders, fakülte ve üniversite dışında öğrencileriyle iletişim veya etkileşiminde etik ilkelere yönelik tutumlarını belirlemek amacıyla dört boyut ve 29 maddeden oluşmaktadır. Haider, Munawar ve Ali (2020) tarafından Pakistan'daki üniversite öğrencilerinin öğretim elemanlarının duygusal dengesi, akademinin ahlaki sorunlarını çözmede ısrarcı olması, İslami değerleri uygulamadaki yeterliği, yeteneklerini anlamaları konusunda öğrencilerle işbirliği 
yapması gibi konularda görüşlerinin belirlenmesi amacıyla 36 madde dört boyuttan oluşan Etik Uygulamalar Ölçeğini geliştirmiştir. Zhu ve Guo (2021) da Çin'deki öğretim elemanlarının kamu, üniversite ve öğrencilerle ilişkilerini ele alan tek boyut ve sekiz maddeden oluşan Öğretim Elemanları Meslek Etiği Ölçeğini geliştirmiştir.

Ulusal alanyazında Gençoğlu (2015) tarafından geliştirilen 53 maddelik altı boyuttan oluşan Öğretim Elemanlarının Mesleki Etik İlkelerine Uyma Düzeyleri Ölçeği bulunmaktadır. Bu ölçekle Kuzey Kıbrıs Türkiye Cumhuriyeti'nde öğretim elemanlarının akademik etik kapsamındaki davranışlarına (topluma, üniversiteye, meslektaşlara, mesleğe ve bilimsel etik ilkelere yönelik davranışlar) ilişkin öğretmen adaylarının görüşlerini belirlemek amaçlanmıştır. Akçamete, Kayhan ve Yıldırım (2017) ise Türkiye'de rehberlik araştırma merkezi, özel eğitim okulu ya da üniversitelerde özel eğitim alanında görev yapan kişilere yönelik Meslek Etiği Ölçeğini geliştirmiştir. Bu doğrultuda çalışanların özel eğitim alanındaki meslek etiği ilkelerini önemseme ve bu ilkelere uyma düzeyleri tek boyut 33 maddelik bir ölçekle belirlenmiştir. Burakgazi-Gelmez ve Can (2018) da Türkiye'de öğretmen adayları için tek boyut 43 maddelik Mesleki Etik Ölçeğini geliştirmiştir. Bu ölçekle öğretmen adaylarının öğretmenlik mesleğine yönelik etik alg1 düzeylerini belirlemek amaçlanmıştır. Bu bağlamda etik konusundaki mevcut ölçeklerin daha çok meslek etiğine yönelik olduğu, bazılarının eğitim-öğretim sürecine yönelik maddeler içerdiği ancak bazılarının bu sürece yönelmediği görülmektedir. Dolayısıyla yükseköğretimde tamamen eğitim-öğretim sürecindeki etik ilkelere yönelen bir ölçme aracının bulunmadığ1 dikkat çekmektedir. Bu sebeple Türkiye örneklemi için yükseköğretimdeki eğitim-öğretim sürecinin öğretim elemanlarının sorumlulukları doğrultusunda etik ilkeler açısından değerlendirilmesine yönelik bir ölçme aracına ihtiyaç duyulmaktadır.

Diğer bir deyişle hem uluslararası hem de ulusal alanyazında eğitim-öğretim etiği ilkelerinin doğrudan öğretim elemanları tarafından ne düzeyde yerine getirildiğini ölçen herhangi bir veri toplama aracına rastlanmamıştır. Bu eksende öğretim elemanlarının öğrencilerin yanı sıra eğitim-öğretim sürecine ilişkin etik sorumluluklarını ne ölçüde sağladıklarının belirlenmesi önemli görülmektedir. Bu kapsamda öğretim elemanlarının eğitim-öğretim etiği ışığında öğrencilere karşı görev ve sorumluluklarını ne seviyede yerine getirdiklerinin tespit edilmesine yardımcı olacak bir ölçme aracına ihtiyaç duyulmaktadır. Bu araştırmada yükseköğretimde öğrencilerin eğitim-öğretim etiğine ilişkin görüşlerini belirleyen geçerli ve güvenilir bir ölçeğin geliştirilmesi amaçlanmaktadır.

\section{Yöntem}

Bu çalışma nicel araştırma yöntemi ile gerçekleştirilen bir ölçek geliştirme çalışmasıdır. Nicel araştırmalar sayısal veriler aracilığıyla kesin ve genellenebilir sonuçlara ulaşmaya çalışmaktadır (Gürbüz ve Şahin, 2017). Bu amaca ulaşmak için ise ölçekler kullanılmaktadır. Davranış bilimlerinde, veri toplama ihtiyacı ortaya çıktığında, araştırmacılar için üç durum söz konusudur. Bunlardan birincisi başka araştırmacılar tarafından geliştirilen ve aynı olguyu ölçmeye yarayan bir ölçme aracı bulup kullanmak, ikincisi, aynı olguyu ölçen ve başka dil ve kültür için geliştirilmiş bir ölçeği hedef dile uyarlamak, üçüncüsü ise yeni bir ölçme aracı geliştirmektir (Yurdabakan ve Çüm, 2017). Aynı olguyu ölçmeye yarayan ölçme araçları alanyazında bulunabilir. Ancak alanyazında yer alan ölçme araçlarının psikometrik özelliklerinin araştırma 
amaçlarını karşılayamaması, hedef kitlenin farklı olması veya ölçme aracının uygulanmasından kaynaklanabilecek zorluklar gibi sebeplerle yeni bir ölçek geliştirme çalışmasına ihtiyaç duyulabilir (Erkuş, 2019). Alanyazında yapılan taramalarda öğretim elemanlarının doğrudan eğitim-öğretim sürecindeki etik davranışlarına yönelen bir ölçme aracına ulaşılamaması, var olan ölçeklerin daha geniş kapsamlı mesleki etik alanlara yönelmesi ve bazı ölçme araçlarının farklı kitleyi hedef alması sebebiyle bu çalışmada yeni bir ölçme aracı geliştirilmeye karar verilmiştir. Ölçek geliştirme çalışmalarının amacı ölçülmesi amaçlanan özelliğin yapısının en iyi şekilde ortaya çıkarılmasıdır (Erkuş, 2019). Bu çalışmada yükseköğretimde eğitimöğretim etiğine yönelik araştırmalara katkı sağlamak amacıyla bu konuya ilişkin bir ölçek geliştirilmeye çalışılmıştır.

Ölçek geliştirme süreci üç temel aşamada gerçekleşmektedir. Madde üretimi olarak adlandırılan ilk aşamada araştırmacı madde havuzu için teorik destek sağlamaktadır. Genellikle "teorik analiz" olarak adlandırılan ikinci aşamada, araştırmacı yeni ölçeğin kapsam geçerliliğini değerlendirerek madde havuzunun istenen yapıyı ölçmeye hizmet etmesini sağlamaktadır. Üçüncü ve son aşama olan psikometrik analizde ise araştırmacı, yeni ölçeğin yapısal geçerliliği ve güvenilirliği olup olmadığını değerlendirmektedir (Morgado vd., 2017). Bu çalışmada da bu temel aşamalar göz önüne alınmıştır.

\section{Çalışma Grubu}

$\mathrm{Bu}$ araştırma iki farklı çalışma grubuyla toplamda 634 üniversite öğrencisiyle yürütülmüştür. Çalışma gruplarının belirlenmesinde amaçlı örnekleme yöntemlerinden ölçüt örneklem tekniğinden (Patton, 2014, s. 230) yararlanılmıştır. Ölçüt olarak çalışma grubundaki öğrencilerin Türkiye'de merkez ve taşra üniversitesinde lisans eğitimi programlarına devam etmesi gözetilmiştir. Buna göre ölçeğin geçerliliği ve güvenirliği kapsamında yapılan açımlayıcı ve doğrulayıcı faktör analizleri farklı çalışma gruplarından toplanan veriler üzerinden yapılmıştır.

Çalışma grubu 1. Ölçek geliştirme çalışmalarında madde sayısının en az beş katı kişiye ulaşılması gerektiği belirtilmektedir (Tabachnick ve Fidell, 2014). Bu sebeple bu araştırma kapsamında açımlayıcı faktör analizini (AFA) gerçekleştirebilmek için en az 250 kişilik bir çalışma grubuna ulaşılmaya çalışılmıştır. Çalışma grubunun belirlenmesinde amaçlı örnekleme yöntemi kullanılmıştır. Çünkü ölçek geliştirme çalışmalarında çalışma grubunun belirlenmesine yönelik en uygun örnekleme yöntemi amaçlı örneklemedir (Erkuş, 2012, 58). Çalışma grubunda yer alacak öğrencilerin belirlenmesinde üniversitenin en az ikinci sınıf düzeyinde olmaları ve eğitim fakültesinde öğrenim görmeleri göz önüne alınmıştır. Çünkü öğretim elemanlarını değerlendirecek bu öğrencilerinin öğretim elemanını gözlemleyebilecek bir deneyime sahip olması ve bunlara ilişkin farkındalığa sahip olması ölçümlerin gerçeğe yakın olması açısından önemlidir. Bu kapsamda eğitim fakültelerinde öğrenim gören toplam 319 gönüllü öğrenciye ulaşılarak taslak ölçek formu bu öğrencilere uygulanmıştır. Tablo 1'de çalışma grubuna ilişkin bilgilere yer verilmiştir. 
Tablo 1

Çalışma Grubu 1'e İlişkin Demografik Bilogiler

\begin{tabular}{|c|c|c|c|}
\hline & Değişkenler & Frekans $(f)$ & Yüzde (\%) \\
\hline \multirow{4}{*}{ Cinsiyet } & Kadın & 229 & 71,8 \\
\hline & Erkek & 88 & 27,6 \\
\hline & Belirtmeyenler & 2 & 6,6 \\
\hline & Toplam & 319 & 100 \\
\hline \multirow{3}{*}{$\begin{array}{l}\text { Sinıf } \\
\text { Düzeyi }\end{array}$} & 3. Sinif & 188 & 58,9 \\
\hline & 4. Sinif & 131 & 41,1 \\
\hline & Toplam & 319 & 100 \\
\hline \multirow{13}{*}{ Bölüm } & Fen Bilgisi Öğretmenliği & 48 & 15,0 \\
\hline & Özel Eğitim Öğretmenliği & 43 & 13,5 \\
\hline & Okul Öncesi Öğretmenliği & 43 & 13,5 \\
\hline & Rehberlik ve Psikolojik Danışmanlık & 38 & 11,9 \\
\hline & Almanca Öğretmenliği & 37 & 11,6 \\
\hline & İngilizce Ö Öretmenliği & 35 & 11,0 \\
\hline & Türkçe Öğretmenliği & 21 & 6,6 \\
\hline & Sosyal Bilgiler Öğretmenliği & 17 & 5,3 \\
\hline & Sınıf Öğretmenliği & 14 & 4,4 \\
\hline & Resim Öğretmenliği & 13 & 4,1 \\
\hline & İlköğretim Matematik Öğretmenliği & 9 & 2,8 \\
\hline & Belirtmeyenler & 1 & 0,3 \\
\hline & Toplam & 319 & 100 \\
\hline
\end{tabular}

Tablo 1'den görüldüğü gibi çalışma grubunda yer alan öğrencilerin $229^{\prime} u$ kadın, $88^{\prime}$ i erkektir. Öğrencilerin 188'i üçüncü sınıf, 131'i dördüncü sınıfta öğrenim görmektedir. Öğrencilerin öğrenim gördükleri bölümlere bakıldığında 48'i fen bilgisi öğretmenliğinde, 43'ü özel eğitim öğretmenliğinde, 43'ü okul öncesi öğretmenliğinde, $38^{\prime} \mathrm{i}$ rehberlik ve psikolojik danışmanlıkta, 37'si Almanca öğretmenliğinde, 35'i İngilizce öğretmenliğginde, $21^{\prime} \mathrm{i}$ Türkçe öğretmenliğinde, 17'si sosyal bilgiler öğretmenliğinde, $14^{\prime}$ ü sinıf öğretmenliğinde, 13'ü resim öğretmenliğinde ve dokuzu ilköğretim matematik öğretmenliğinde öğrenim görmektedir.

Çalışma grubu 2. Araştırmada AFA' dan sonra doğrulayıcı faktör analizi (DFA) için yeni bir çalışma grubundan veriler toplanmıştır. Buna göre ikinci çalışma grubunun belirlenmesinde de öğrencilerin en az ikinci sınıfta öğrenim görmeleri ölçütü dikkate alınmıştır. Toplam 315 öğrenciye ulaşılmıştır. Tablo 2' de ikinci çalışma grubuna ilişkin demografik bilgilere yer verilmiştir.

Tablo 2'de görüldüğü üzere öğrencilerin 236's1 (\%74.9) kadın, 79'u (\%25.1) erkektir. 71 öğrenci (\%22.5) ikinci sinıfta, 85 öğrenci (\%27.0) üçüncü sınıfta, 159 öğrenci (\%50.5) ise dördüncü sinıfta öğrenim görmektedir. Öğrencilerin bölümleri incelendiğinde $82^{\prime} \mathrm{si} \quad(\% 26.0)$ sinıf öğretmenliğinde, 46 's1 (\%14.6) İngilizce öğretmenliğinde, 43’ü (\%13.7) sosyal bilgiler öğretmenliğinde, 42'si (\%13.3) özel eğitim öğretmenliğinde, 36'sı (\%11.4) okul öncesi öğretmenliğinde, 34'ü (\%10.8) fen bilgisi öğretmenliğinde, 16's1 Almanca öğretmenliğinde, 14'ü rehberlik ve psikolojik danışmanlık bölümünde öğrenim görmektedir. İki öğrenci öğrenim gördüğü bölüm sorusuna cevap vermemiştir. 
Tablo 2

Çalışma Grubu 2'ye İlişkin Demografik Bilgiler

\begin{tabular}{clcc}
\hline & Değişkenler & Frekans $(f)$ & Yüzde (\%) \\
\hline \multirow{3}{*}{ Cinsiyet } & Kadın & 236 & 74.9 \\
& Erkek & 79 & 25.1 \\
& Toplam & 315 & 100 \\
\hline \multirow{5}{*}{ Sınıf Düzeyi } & 2. Sınıf & 71 & 22.5 \\
& 3. Sınıf & 85 & 27 \\
& 4. Sınıf & 159 & 50.5 \\
& Toplam & 315 & 100 \\
\hline \multirow{5}{*}{ Bölüm } & Sınıf Öğretmenliği & 82 & 26.0 \\
& İngilizce Öğretmenliği & 46 & 14.6 \\
& Sosyal Bilgiler Öğretmenlĭ̆i & 43 & 13.7 \\
& Özel Eğitim Öğretmenliği & 42 & 13.3 \\
& Okul Öncesi Öğretmenlï̆i & 36 & 11.4 \\
& Fen Bilgisi Öğretmenliği & 34 & 10.8 \\
& Almanca Öğretmenliği & 16 & 5.07 \\
& Rehberlik ve Psikolojik Danışmanlık & 14 & 4.44 \\
& Belirtmeyenler & 2 & 0.63 \\
& Toplam & 315 & 100 \\
\hline
\end{tabular}

\section{Ölçeğin Geliştirilme Süreci}

Madde havuzunun oluşturulması. Yükseköğretimde eğitim-öğretim etiği ölçeği öğrenci formu geliştirirken öncelikle madde havuzu oluşturulmaya çalışılmıştır. Deneme uygulaması için, geniş bir madde havuzu oluşturulması, geliştirilecek ölçeğin kapsam geçerliliğini sağlamak açısından önem taşımaktadır (Yurdabakan ve Çüm, 2017). Madde havuzu oluşturulurken tümevarım, tümdengelim ya da her ikisinin kombinasyonu yöntemler kullanılabilmektedir. Tümdengelimli yöntemler, kapsamlı bir alanyazın taramasına ve önceden var olan ölçeklere dayalı madde oluşturmayı içermektedir (Morgado vd., 2017). Bu yaklaşım, araştırılacak olgunun anlaşılmasını ve incelenmekte olan yapının teorik tanımını geliştirmek için alanyazının kapsamlı bir incelemesini gerektirmektedir (Hinkin, 1995). Buna göre madde havuzunu oluşturabilmek için öncelikle alanyazın taraması yapılmıştır. Nitekim ölçek geliştirme çalışmalarının ilk adımı olarak konuyla alakalı alanyazın taraması yapmak (Karakoç ve Dönmez, 2014) da belirtilmektedir. Bu kapsamda hem yapılan araştırmalar hem de YÖK'ün yükseköğretim kurumları etik davranış ilkeleri rehberi incelenmiştir. Öte yandan, tümevarım yöntemleri, madde geliştirmeyi hedef kitleden bir yapıya ilişkin toplanan görüşlerden elde edilen nitel bilgilere dayandırmaktadır (Morgado vd., 2017). Bu nedenle daha sonra eğitim fakültesinde son sınıfta öğrenim gören beş öğrenciyle görüşmeler yapılmıştır. Görüşmeler yazıya aktarılarak araştırmacılar tarafından birlikte incelenmiş ve ilgili dokümanlardan yeni maddeler oluşturulmuştur. Böylece 52 maddelik taslak form oluşturulmuştur. Diğer bir deyişle bu çalışmada madde havuzu oluştururken hem tümdengelim hem de tümevarım yöntemlerinden yararlanılmıştır.

Kapsam geçerliliğinin sağlanması. Kapsam geçerliliği bir ölçme aracının ilgili olguyu ve buna ilişkin davranışları ne kadar iyi ölçtüğünü kararlaştırma olayıdır 
(Balc1, 2015). Ölçek maddelerine göre çıkarımlar yapıldı̆̆ı için kapsam geçerliliğinin değerlendirilmesi ölçek geliştirme çalışmalarında bir gerekliliktir. Araştırmacı, kapsam geçerliliğini sağlamak için işlemsel hale getirilmiş maddeler hakkında görüş almaktadır. Bu görüşü alan uzmanlarından alabileceği gibi uygulama yapılacak hedef kitleden de alabilir (Morgado vd., 2017). Bu çalışmada ölçeğin ve ölçekte yer alan maddelerin amaca ne kadar hizmet ettiğini, diğer bir deyişle kapsam geçerliliğini sağlayabilmek için uzman görüşü tekniğine başvurulmuştur. Yaratan (2017) ölçeğin kapsam geçerliliğini sağlayabilmek için en az üç uzmanın görüşüne başvurulması gerektiğini ifade etmektedir. Bu kapsamda bu çalışmada sekiz alan uzmanının görüşüne başvurulmuştur. Uzmanlara gönderilen taslak formda 52 madde yer almaktadır. Uzmanlardan formda yer alan 52 maddenin her biri için (a) uygun, (b) madde hafifçe gözden geçirilmeli, (c) madde ciddi olarak gözden geçirilmeli ve (d) madde uygun değil şeklinde sunulan derecelendirmelerden birisini işaretlemeleri istenmiştir. Ayrıca b ve c seçeneği işaretleyen uzmanlardan önerilerini yazmaları, d seçeneği işaretleyen uzmanlardan ise maddeyi neden uygun görmediklerini açıklamaları talep edilmiştir. Madde Kapsam Geçerliği İndeksi (I-CVI) a veya b seçeneğini işaretleyen uzmanların sayısının toplam uzman sayısına bölünmesiyle hesaplanmıştır. Ölçek Kapsam Geçerliği Indeksi (S-CVI/Ave) ise her bir maddenin ICVI puanı toplanıp madde sayısına bölünerek hesaplanmıştır. Uzman görüşleri doğrultusunda hesaplanan I-CVI değerleri Tablo 3'te sunulmuştur.

Tablo 3

Uzman Görüşleri Doğrultusunda Ölçeğe Ait Kapsam Geçerlik İndeksleri

\begin{tabular}{|c|c|c|c|c|c|c|c|c|c|c|c|}
\hline $\begin{array}{l}0 \\
z \\
\frac{0}{0} \\
\frac{\pi}{2} \\
\sum\end{array}$ & 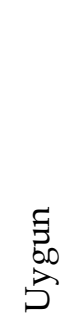 & 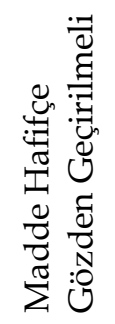 & 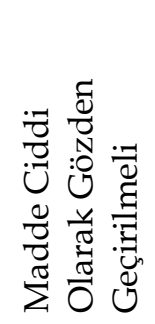 & 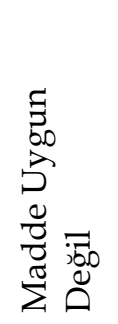 & $\sum_{\perp}$ & $\begin{array}{l}0 \\
z \\
\frac{\theta}{0} \\
\frac{\pi}{\pi} \\
\Sigma\end{array}$ & $\begin{array}{l}\Xi \\
5 \\
\sigma \\
\sigma\end{array}$ & 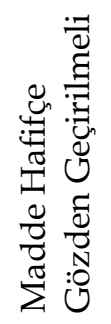 & 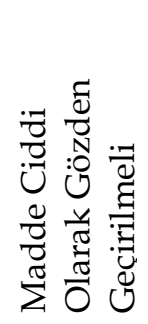 & 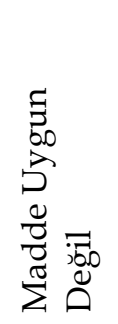 & 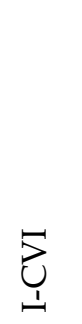 \\
\hline 1 & 5 & 2 & 1 & 0 & .875 & 27 & 8 & 0 & 0 & 0 & 1.00 \\
\hline 2 & 8 & 0 & 0 & 0 & 1.00 & 28 & 8 & 0 & 0 & 0 & 1.00 \\
\hline 3 & 6 & 2 & 0 & 0 & 1.00 & 29 & 8 & 0 & 0 & 0 & 1.00 \\
\hline 4 & 8 & 0 & 0 & 0 & 1.00 & 30 & 8 & 0 & 0 & 0 & 1.00 \\
\hline 5 & 5 & 2 & 1 & 0 & .875 & 31 & 7 & 1 & 0 & 0 & 1.00 \\
\hline 6 & 6 & 2 & 0 & 0 & 1.00 & 32 & 7 & 0 & 1 & 0 & .875 \\
\hline 7 & 8 & 0 & 0 & 0 & 1.00 & 33 & 7 & 0 & 1 & 0 & .875 \\
\hline 8 & 8 & 0 & 0 & 0 & 1.00 & 34 & 4 & 4 & 0 & 0 & 1.00 \\
\hline
\end{tabular}




\begin{tabular}{|c|c|c|c|c|c|c|c|c|c|c|c|}
\hline $\begin{array}{l}0 \\
z \\
\frac{0}{0} \\
\frac{\pi}{2} \\
\sum\end{array}$ & $\begin{array}{l}\Xi \\
\vdots \\
\vdots \\
\vdots \\
\vec{b}\end{array}$ & 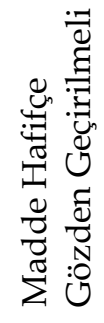 & 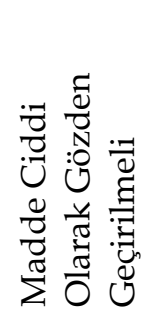 & 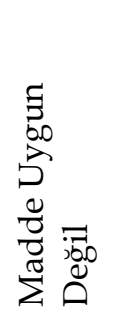 & 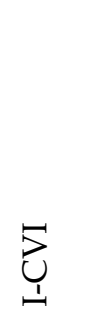 & $\begin{array}{l}0 \\
z \\
\frac{0}{0} \\
\frac{\pi}{\pi}\end{array}$ & $\begin{array}{l}5 \\
\vdots \\
\vdots \\
\vdots \\
\vdots\end{array}$ & 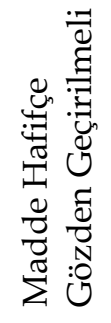 & 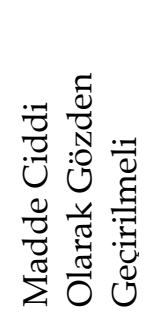 & 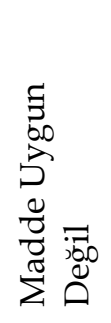 & $\underbrace{\longrightarrow}_{\perp}$ \\
\hline 9 & 7 & 1 & 0 & 0 & 1.00 & 35 & 7 & 1 & 0 & 0 & 1.00 \\
\hline 10 & 8 & 0 & 0 & 0 & 1.00 & 36 & 8 & 0 & 0 & 0 & 1.00 \\
\hline 11 & 7 & 1 & 0 & 0 & 1.00 & 37 & 6 & 2 & 0 & 0 & 1.00 \\
\hline 12 & 8 & 0 & 0 & 0 & 1.00 & 38 & 8 & 0 & 0 & 0 & 1.00 \\
\hline 13 & 8 & 0 & 0 & 0 & 1.00 & 39 & 8 & 0 & 0 & 0 & 1.00 \\
\hline 14 & 7 & 1 & 0 & 0 & 1.00 & 40 & 7 & 1 & 0 & 0 & 1.00 \\
\hline 15 & 8 & 0 & 0 & 0 & 1.00 & 41 & 6 & 2 & 0 & 0 & 1.00 \\
\hline 16 & 7 & 0 & 1 & 0 & .875 & 42 & 8 & 0 & 0 & 0 & 1.00 \\
\hline 17 & 8 & 0 & 0 & 0 & 1.00 & 43 & 8 & 0 & 0 & 0 & 1.00 \\
\hline 18 & 8 & 0 & 0 & 0 & 1.00 & 44 & 8 & 0 & 0 & 0 & 1.00 \\
\hline 19 & 8 & 0 & 0 & 0 & 1.00 & 45 & 7 & 1 & 0 & 0 & 1.00 \\
\hline 20 & 5 & 0 & 1 & 2 & $.625^{*}$ & 46 & 8 & 0 & 0 & 0 & 1.00 \\
\hline 21 & 6 & 1 & 1 & 0 & .875 & 47 & 5 & 2 & 0 & 1 & .875 \\
\hline 22 & 7 & 1 & 0 & 0 & 1.00 & 48 & 7 & 1 & 0 & 0 & 1.00 \\
\hline 23 & 8 & 0 & 0 & 0 & 1.00 & 49 & 8 & 0 & 0 & 0 & 1.00 \\
\hline 24 & 6 & 1 & 1 & 0 & .875 & 50 & 8 & 0 & 0 & 0 & 1.00 \\
\hline 25 & 6 & 2 & 0 & 0 & 1.00 & 51 & 6 & 2 & 0 & 0 & 1.00 \\
\hline 26 & 7 & 1 & 0 & 0 & 1.00 & 52 & 5 & 2 & 1 & 0 & .875 \\
\hline
\end{tabular}

Tablo 3'ten görüldüğ ü gibi maddelerin kapsam geçerlik indeksleri .625 ile 1.00 arasında değişmekte olup ölçeğin toplamına ilişkin Ölçek Kapsam Geçerlik İndeksi 95 olarak hesaplanmıştır. Lynn (1986) sekiz uzmanın katıldı̆̆ı bir panelde madde kapsam geçerlik indekslerinin en az .83 olması gerektiğini önermektedir. Ölçek Kapsam Geçerlik İndeksinin ise .80 ve üzerinde olması kabul edilebilir değer olarak ifade edilmektedir (Polit ve Beck, 2006). Buna göre 20. madde olan "Ders kitaplarının fotokopi ile çoğaltılmasına izin vermez." ifadesinin madde kapsam geçerlik değeri kritik değerin altında olduğundan ölçek formundan çıkarılmıştır. Ölçeğin kapsam geçerlik indeksi ise kabul edilebilir düzeydedir. Bu durumda taslak ölçekte 51 madde kalmıştır. Formda düzeltilmeli görüşü belirtilen maddeler tekrar gözden geçirilmiş ve bazı maddelerin ifadelerinde değişiklikler yapılmıştır. Örneğin “Öğretim elemanları dersle ilgili eylem ve uygulamalarında tutarlıdır" ifadesi uzman görüşleri doğrultusunda "Öğretim elemanları dersle ilgili söylem ve eylemlerinde tutarlıdır" şeklinde düzeltilmiştir. Sonrasında bu form bir Türk Dili uzmanına sunulmuştur ve uzmandan gelen dönütler sonrasında ifadeler Türkçe dilbilgisi kurallarına göre düzenlenmiştir. Buna göre ön uygulama öncesi taslak formun 51 maddeden oluşmuştur. 5'li likert tipinde derecelendirilen ölçekte, ifadeler "1-Hiç katılmıyorum", “5-Tamamen katılıyorum" olacak şekilde derecelendirilmiştir.

\section{Verilerin Toplanması ve Analizi}

Ölçek geliştirme aşamasının üçüncü aşaması olan yapı geçerliliğini ve güvenilirliğini sağlamak için veriler, hedef popülasyonun yeterli ve uygun bir temsili örneklemine 
uygulanmalıdır (Morgado vd., 2017). Bu kapsamda yapı geçerliğini test etmek için taslak form üniversite öğrencilerine uygulanmıştır. Yapı geçerliliğini sağlamanın iki yolu bulunmaktadır. Bunlardan ilki faktör analizi ikincisi bilinen grup ya da önceden geçerliliği tespit edilmiş bir ölçme aracı ile karşılaştırılmasıdır (Balcı, 2015). Bu çalışmada veriler toplandıktan sonra ölçeğin yapısını ortaya koyabilmek için temel bileşenler analizine dayalı AFA yapılmıştır. AFA bir ölçekte yer alan maddeler ile ölçmesi gereken yapı ya da özellikler ile olan ilişkisini ortaya koyan bir yöntemdir (Yaratan, 2017). Dolayısıyla bu yöntem ölçme aracının ölçtüğü düşünülen yapı ya da faktörlerin sayısının bilinmediği durumlarda kullanılmakta ve ölçme aracıyla ölçülen faktörlerin doğası hakkında bilgi edinmeye çalışılmaktadır (Balcı, 2015).

AFA ile belirlenen yapının doğruluğunu sınamak için DFA de yapılmıştır. Çünkü Gürbüz ve Şahin' in (2017) belirttiği üzere bir ölçeğin DFA ile doğrulanması, o ölçeğin geçerli olduğuna işaret etmektedir. DFA için farklı bir çalışma grubundan veriler toplanmıştır. Bu kapsamda AFA ile geliştirilen ölçek öğrencilere uygulanmıştır. Ölçeğin iç tutarlılık güvenirliği için ise Cronbach alfa katsayısı, maddelerin düzeltilmiş madde toplam korelasyonları ve kompozit güvenirlik katsayısı hesaplanmıştır. Veri analizinde SPSS ve AMOS programlarından yararlanılmıştır.

\section{Araştırmanın Etik İzinleri}

Yapılan bu çalışmada "Yükseköğretim Kurumları Bilimsel Araştırma ve Yayın Etiği Yönergesi" kapsamında uyulması belirtilen tüm kurallara uyulmuştur. Yönergenin ikinci bölümü olan "Bilimsel Araştırma ve Yayın Etiğine Aykırı Eylemler" başlığı altında belirtilen eylemlerden hiçbiri gerçekleştirilmemiştir.

Etik kurul izin bilgileri

Etik değerlendirmeyi yapan kurul adı= Trakya Üniversitesi Sosyal ve Beşeri Bilimler Etik Kurulu

Etik değerlendirme kararının tarihi $=06.05 .2020$

Etik değerlendirme belgesi sayı numarasi=29563864-050.04.04-E.432843

\section{Bulgular}

Bu başlık altında araştırma kapsamında yapılan analizler sırasıyla açıklanmıştır.

\section{Geçerliliğe İlişkin Bulgular}

Ölçeğin yapı geçerliliğini test etmek amacıyla yapılan açımlayıcı faktör analizine ve doğrulayıcı faktör analizine yönelik bulgular ilgili başlıklar altında sunulmuştur.

Açımlayıcı faktör analizine ilişkin bulgular. AFA'da ilk olarak kayıp veri ve uç değer analizleri yapılmıştır. Veri setinde kayıp veri oranının $\% 5^{\prime}$ ten az olmasına dikkat edilmiştir (Tabachnick ve Fidell, 2014, 97). Kayıp verilere ortalama değer atanmıştır. Değiş̧kenlerin olası sınırlar (1-5) içerisinde olup olmadığı kontrol edilmiştir. Tek değişkenli uç değerler standartlaştırılmış z puanları ile incelenmiştir. Buna göre z puanı aralığının -3.00 ile +3.00 arasında olması gerekmektedir (Tan, 2016). $\mathrm{Bu}$ değerler dışında bulunan değerler (12 veri) veri setinden çıkarılmıştır. Ayrıca çok değişkenli uç değerler için Mahalonobis uzaklık değerleri incelenmiş ve uç değerler (21 veri) veri setinden çıkarılmışır. Maddeler arasındaki korelasyonlar $(r<0.80)$ incelendiğinde çoklu bağlantı problemi tespit edilmemiştir. Faktör sayısını tespit edebilmek adına istatistik çözümlemelerin kullanılabilmesi için çok değişkenliği normalliğin sağlanması gerekli görülmektedir (Çokluk, Şekercioğlu ve Büyüköztürk, 
2012). Bu kapsamda öncelikle tek değişkenli normalliğin sağlanması için basıklık ve çarpıklık katsayıları incelenmiş ve bu katsayıların \pm 1 aralığında olduğu görülmüştür. Histogram, Q-Q plot ve kutu-bıyık grafiklerine göre de değişkenler normal dağılmaktadır. Ayrıca çok değişkenli normallik için Bartlett küresellik testi incelenmiş anlamlı bulunmuştur. Buna göre veri setinin normal dağılım gösterdiği kabul edilmiştir. Bu kapsamda 286 veri ile analizler gerçekleştirilmiştir.

AFA'nın ölçek geliştirme süreçlerinde asıl amacı maddeler yani değişkenler arasındaki ilişki katsayıları matrisinden birbirleri ile ilişkili olan maddeleri bir araya getirerek kendi içerisinde tutarlı boyutlar oluşturmak ve ölçülmek istenen yapıyı az sayıda maddeyle ve mümkün olan en yüksek varyansla açıklamaktır (Yurdabakan ve Çüm, 2017). Bu kapsamda da yükseköğretimde eğitim-öğretim etiğine yönelik maddelerin birbiriyle ilişkili olanlarını tespit edip ölçeğin boyutlarını belirleyebilmek için temel bileşenler analizine dayalı açımlayıcı faktör analizi yapılmıştır. Verilerin faktör analizi açısından uygun olup olmadığı Kaiser-Meyer-Olkin (KMO) ve Bartlett Küresellik Testi ile incelenmiştir. Analiz sonucu KMO değerinin .911 olmas1 değişkenlerin faktör analizi için iyi olduğunu göstermektedir (Tavşancıl, 2014). Ayrıca Bartlett küresellik testi maddeler arasında korelasyon olup olmadığını incelemektedir (Yaratan, 2017). Yapılan analiz sonucu Bartlett küresellik testinin sonucu anlamlı bulunmuş $\left(x^{2}(276)=2956.46 ; p<0.01\right)$, maddeler arasında korelasyon olduğu sonucuna ulaşılmıştır.

Açımlayıcı faktör analizi sonuçlarına göre maddeler özdeğeri 1'in üstünde olan toplam 10 boyut altında toplanmaktadır. Bunun üzerine Şekil 1'de yer alan modelin yamaç birikinti (scree plot) grafiği incelenmiştir.

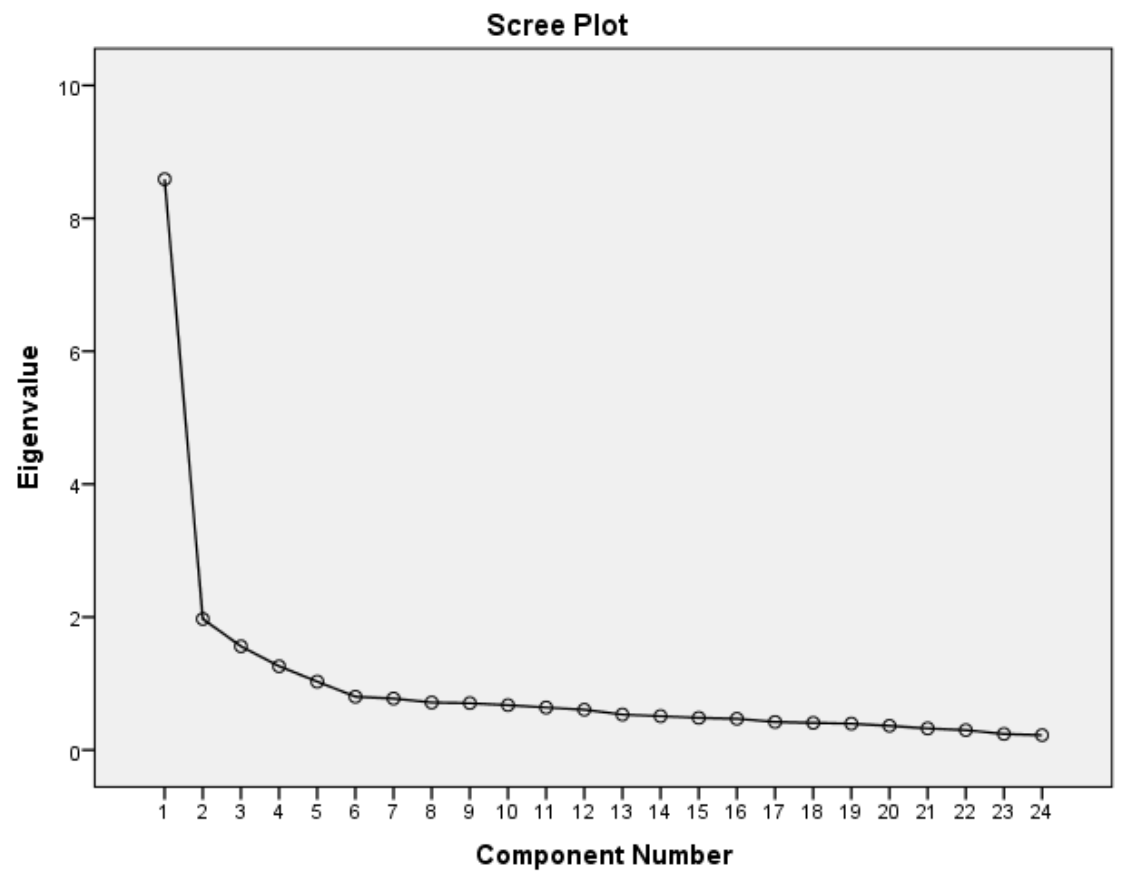

Şekil 1. Modelin yamaç-birikinti grafiği

Şekil 1'de görüldüğü gibi maddelerin yamaç birikinti (scree plot) grafiği incelendiğinde ölçeğin tek boyut ya da beş boyut olarak yapılandırılabileceği görülmüştür. Ancak en keskin kırılmanın birinci faktörden sonra gerçekleştiği görülmektedir. Faktör yük dağılımını daha iyi görebilmek için döndürme yöntemi kullanılmasına karar verilmiştir. Faktörlerin birbiriyle ilişkili olduğu durumlarda eğik 
döndürme yöntemleri kullanılabilmektedir (Büyüköztürk, 2002). Psikolojik yapının faktöriyel yapısının tümüyle ilişkili ya da ilişkisiz olduğu kabul edilemez (Erkuş, 2012). Bu çalışmada da faktörler arasında tümüyle ilişkisiz olma durumu söz konusu değildir. Bu nedenlerle döndürme yöntemi olarak eğik döndürme yöntemlerinden Direct Oblimin seçilerek analizler yenilenmiştir. Döndürme yöntemiyle binişik çıkan maddeler sırasıyla ve teker teker çıkarılarak analizler yeniden yapılmıştır. Yapılan tüm analizler sonrası ölçeğin toplam 24 madde ve beş boyutlu olarak yapılandığı görülmüştür.

Analiz sonucu ortaya çıkan beş boyutlu yapının açıkladığı toplam varyans \%60.040 olarak bulunmuştur. Sosyal bilimler için bu oran yeterli görülmektedir (Scherer, Wiebe, Luther ve Adams, 1988; Akt. Tavşanc1l, 2014, 48). Boyutların açıkladıkları varyanslara bakıldığında birinci boyutun \%35.79 (özdeğeri=8.59), ikinci boyutun \%6.21 (özdeğeri=1.97), üçüncü boyutun \%6.50 (özdeğeri=1.56), dördüncü boyutun \%5.25 (özdeğeri=1.26), beşinci boyutun \%4.29 (özdeğeri=1.03) olduğu görülmüştür. Birinci faktörün yalnız başına değişkenin \%35'ini tek başına açıklaması, ayrıca birinci faktörün özdeğeri (8.589) ve ikinci faktörün özdeğeri (1.971) arasındaki farka dayanarak ölçeğin tek faktörlü ancak çok bileşenli bir yap1 gösterdiği söylenebilir. Ayrıca yamaç-birikinti grafiğinde de birinci faktörden sonra keskin bir düşüş olduğu, daha sonra yatayına bir değişim olduğu göze çarpmaktadır. Nitekim birinci faktörün özdeğerinin ve açıkladığı varyansın yüksek olması, bu değerlerin ikinci faktörde düşük olması ve bunun yanında ikinci faktör ile diğer faktörlerin özdeğerlerinin birbirine yakın olması ölçeğin tek faktörlü olduğunun göstergeleri olarak kabul edilmektedir (Çokluk, Şekercioğlu ve Büyüköztürk, 2012). Buna göre ölçeğin 24 madde ile tek faktörlü beş bileşenli bir yap1 gösterdiği kabul edilmiştir. Maddelerin faktör yük değerleri .395 ile .880 arasında değişmektedir. Ölçeğin açımlayıcı faktör analizi sonuçlarına Tablo 4 'te yer verilmiştir.

Tablo 4

Ölçeğin Açımlayıcı Faktör Analizi Sonuçları

\begin{tabular}{|c|c|c|}
\hline Maddeler & $\begin{array}{l}\text { Faktör } \\
\text { Yükleri }\end{array}$ & $\begin{array}{c}\text { Madde } \\
\text { Toplam } \\
\text { Korelasyonları } \\
\end{array}$ \\
\hline \multicolumn{3}{|l|}{ Bileşen 1: Öğrencilere Sayg1 Gösterme } \\
\hline $\begin{array}{l}\text { M27. Öğretim elemanları öğrencileri değerlendirme yetkisini baskı ya } \\
\text { da tehdit aracı olarak kullanmaz. }\end{array}$ & .636 & .561 \\
\hline $\begin{array}{l}\text { M30. Öğretim elemanları öğrencilerin derse yönelik görüş ve önerilerini } \\
\text { dikkate alır. }\end{array}$ & .472 & .642 \\
\hline M36. Öğretim elemanları tüm öğrencilere eşit ve tarafsız davranır. & 691 & .636 \\
\hline $\begin{array}{l}\text { M37. Ö̆ğretim elemanları öğrencileri küçük düşürecek söz ve } \\
\text { eylemlerde bulunmaz. }\end{array}$ & .853 & .551 \\
\hline $\begin{array}{l}\text { M38. Öğretim elemanları öğrencilere karşı uygun bir üslup ve hitap } \\
\text { kullanır }\end{array}$ & .770 & .595 \\
\hline
\end{tabular}


çıkılarak "Öğrencilere saygı gösterme” olarak isimlendirilmiştir. İkinci bileşen üç maddeden oluşmakta ve toplam varyansın \%8.21'ini açıklamaktadır. Bu bileşendeki maddelerin faktör yük değerleri .700 ile .880 arasında değişmektedir. Bu bileşen, içinde yer alan maddeler göz önüne alınarak "Derse ilişkin bilgilendirme" olarak isimlendirilmiştir. Üçüncü bileşen olan "Öğrencilerin korunması" ise toplam altı maddeden oluşmakta ve toplam varyansın \%6.51'ini açıklamaktadır. Bu bileşendeki faktör yük değerleri .395 ile .800 arasında değişmektedir. Dördüncü bileşen beş maddeden oluşmakta ve toplam varyansın \%5,25'ini açıklamaktadır. Bu bileşendeki faktör yük değerleri .402 ile .820 arasında değişmekte olup bileşen "Öğretim elemanının yeterliliğ $i$ " olarak isimlendirilmiştir. Son bileşen olan yapı ise "Öğrencileri önemseme" olarak isimlendirilmiştir. Bu bileşendeki faktör yük değerleri .515 ile .758 arasında olup toplam varyansın \% 4.29'unu açıklamıştır. Açımlayıcı faktör analizi sonuçlarına göre Yükseköğretimde Eğitim-Öğretim Etiği Ölçeği Öğrenci Formu tek faktör ve beş bileşenli bir yapıyla \%60.04'lük bir varyansı açıklamaktadır. Bileşenlerin kendi içlerindeki ve toplam puanla aralarındaki korelasyon katsayıları Tablo 5'te sunulmaktadir.

Tablo 5

Bileşen ve Toplam Puan Korelasyonları

\begin{tabular}{lllllll}
\hline & 1. Bileşen & 2. Bileşen & 3. Bileşen & 4. Bileşen & 5. Bileşen & Toplam Puan \\
\hline 1.Bileşen & 1.00 & $.58^{* *}$ & $.52^{* *}$ & $.53^{* *}$ & $.57^{* *}$ & $.60^{* *}$ \\
2. Bileşen & $.58^{* *}$ & 1.00 & $.61^{* *}$ & $.56^{* *}$ & $.70^{* *}$ & $.71^{* *}$ \\
3. Bileşen & $.52^{* *}$ & $.61^{* *}$ & 1.00 & $.68^{* *}$ & $.64^{* *}$ & $.76^{* *}$ \\
4. Bileşen & $.53^{* *}$ & $.56^{* *}$ & $.68^{* *}$ & 1.00 & $.62^{* *}$ & $.76^{* *}$ \\
5. Bileşen & $.57^{* *}$ & $.70^{* *}$ & $.64^{* *}$ & $.62^{* *}$ & 1.00 & $.83^{* *}$ \\
\hline
\end{tabular}

Tablo 5'ten görüldüğü gibi bileşenlerin hem kendi içlerinde hem de toplam puanla aralarında pozitif yönde anlamlı ilişki bulunmaktadır. Beş bileşenli modelde görülen bileşenlerin sahip olduğu toplam puan korelasyonlarının istenilen değer aralığında olması ölçme modelinin uygunluğunu göstermektedir (Kline, 2005). Her bir bileşenin toplam puanla ilişkisi ise diğer bileşenlerle ilişkisinden daha yüksektir. Bu durum da ölçeğin tek faktörlü ancak çok bileşenli olduğunu göstermektedir.

Doğrulayıcı faktör analizine ilişkin bulgular. DFA'ya başlamadan önce kayıp veri analizi yapılmış ve veri setinde kayıp veri oranının $\% 5^{\prime}$ ten az olduğu görülmüş, kayıp verilere ise ortalama değer atanmıştır (Tabachnick ve Fidell, 2014, 97). Kayıp veri analizinin ardından uç değer analizi yapılmıştır. Tek değişkenli uç değerler standartlaştırılmış z puanları ile, çok değişkenli uç değerler Mahalanobis uzaklık değerleri ile incelenmiştir. Buna göre veri setinden 15 uç değer çıkarılmış ve analizler 300 gözlemden oluşan veri setiyle gerçekleştirilmiştir. Verilerin normalliğinin tespitinde basıklık ve çarpıklık katsayıları hesaplanmış ve grafiksel incelemeler yapılmıştır. Basıklık ve çarpıklık katsayıların \pm 1 aralığında olduğu görülmüştür. Histogram, Q-Q plot ve kutu-bıyık grafiklerine göre de değişkenler normal dağılım göstermektedir. 
Yapılan analizler sonucu belirlenen ölçek yapısının doğruluğunu sınamak için birinci ve ikinci düzey DFA yapılmıştır. DFA'da modelin veriye ne derece uyumlu olduğunu gösteren farklı uyum istatistikleri belirlenmiştir (Schermelleh-Engel, Moosbrugger ve Müller, 2003). En eski ve en yaygın kullanılan uyum indeksi $\chi 2$ değeri olsa da bu değere ek olarak farklı değerlerden de yararlanılmaktadır. Çünkü kullanılan her bir uyum iyiliği indeksinin güçlü ve zayıf yönleri bulunmaktadır, bu nedenle modelin doğrulanıp doğrulanmadığına sadece tek bir uyum indeksine bakarak karar verilmemelidir (Gürbüz ve Şahin, 2017). X2 değerinden sonra en sık rapor edilen uyum indeksleri RMSEA, GFI, AGFI, CFI ve NFI değerleridir (Sümer, 2000). Bu sebeple bu çalışmada bu uyum indeksleri incelenerek modelin doğrulanıp doğrulanmadığına karar verilmiştir. Araştırmada ikinci düzey DFA sonucu elde edilen model uyum iyiliği indeksleri ile ölçüt alınan uyum iyiliği istatistikleri Tablo $6^{\prime}$ da sunulmuştur.

Tablo 6

Doğrulayıcı Faktör Analizinde Kullanılan Uyum İyiliği Ölçütleri ve Model Uyum İyiliği İndeksleri

\begin{tabular}{lccc}
\hline Uyum Ölçütleri & Mükemmel Uyum & Kabul Edilebilir Uyum & Ölçek \\
\hline$\chi^{2} /$ sd & $0.00 \leq \chi^{2} / \mathrm{sd} \leq 3.00$ & $3.00 \leq \chi^{2} / \mathrm{sd} \leq 5.00$ & 1.87 \\
RMSEA & $0 \leq \mathrm{RMSEA} \leq .05$ & $.05<\mathrm{RMSEA} \leq .08$ & .05 \\
$\mathrm{NFI}$ & $.95 \leq \mathrm{NFI} \leq 1.00$ & $.80 \leq \mathrm{NFI}<.95$ & .89 \\
CFI & $.95 \leq \mathrm{CFI} \leq 1.00$ & $.85 \leq \mathrm{CFI}<.95$ & .94 \\
GFI & $.90 \leq \mathrm{GFI} \leq 1.00$ & $.80 \leq \mathrm{GFI}<.90$ & .89 \\
AGFI & $.95 \leq \mathrm{AGFI} \leq 1.00$ & $.85 \leq \mathrm{AGFI}<.95$ & .86 \\
\hline
\end{tabular}

Kaynak: Simon vd., 2010, 239.

Tablo 6'ya göre ölçeğin ikinci düzey DFA'sından elde edilen bulgular değerlendirildiğinde, $\chi 2$ /sd oran 1.87 ( $\chi 2$ /sd $\leq 3$ ), RMSEA=0.05 (RMSEA $\leq .05$ ) olarak hesaplanmıştır. Bu değerler model-veri uyumunun iyi olduğuna işaret etmektedir. Diğer uyum indeksleri incelendiğinde ise (NFI=.89, CFI =.94, GFI =.89, AGFI =.86) modelin iyi uyum gösterdiğini ortaya koymaktadır (Simon vd., 2010). İkinci düzey DFA modeli Şekil 2'de sunulmuştur. 


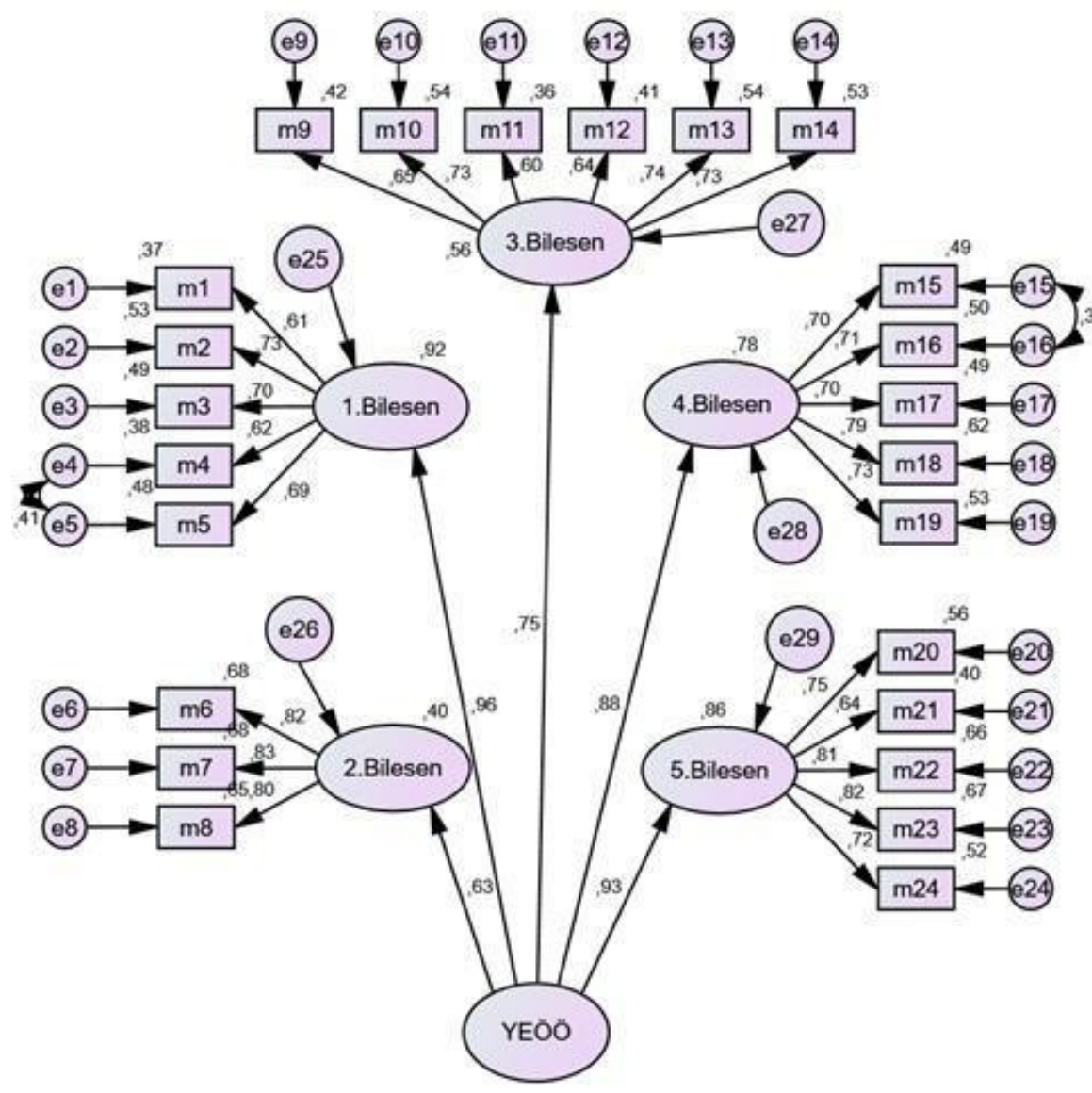

Şekil 2. Ölçeğin ikinci düzey DFA modeli

Ölçeğin faktörler arası ilişkilerinin yer aldı ̆̆ı rol diyagramını sunan Şekil 2'de standardize edilmiş regresyon ağırlıkları görülmektedir. Öğrencilere saygı gösterme olarak isimlendirilen birinci bileşeni açıklayan ifadelerin standartlaştırılmış yol yüklerinin hepsinin pozitif ve yüksek korelasyona (.61 ve .73 arası) sahip olduğu görülmektedir. İkinci bileşen olan Derse ilişkin bilgilendirme için ifadelerin standartlaştırılmış yol yükleri .80 ve .83 arasında değişmekte, üçüncü bileşen olan Öğrencilerin korunması için .56 ve .73 arasında, Öğretim elemanının yeterliliği olarak isimlendirilen dördüncü bileşende standartlaştırılmış yol yükleri .70 ve .79 arasında değişmektedir. Son bileşen olan Öğrencileri önemseme için maddelerin standartlaştırılmış yol yükleri .64 ve .82 arasında değer ile pozitif ve yüksek korelasyona sahiptir. Yükseköğretimde eğitim öğretim etiğinin birinci bileşenle arasında anlamlı ve güçlü iliş̧i olduğu görülmektedir (.96). bu değer birinci bileşendeki bir puanlık artışın yükseköğretimde eğitim ve öğretim etiğinde $.96^{\prime}$ lik artışa neden olacağını göstermektedir. Benzer şekilde yükseköğretimde eğitim ve öğretim etiğinin ikinci bileşen (.63), üçüncü bileşen (.75), dördüncü bileşen (.88) ve beşinci bileşenle (.93) de pozitif ve yüksek ilişkiye sahip olduğu görülmektedir.

\section{Güvenirliğe İlişkin Bulgular}

Geliştirilen ölçme aracının güvenirliğini belirleyebilmek için iç tutarlılık katsayısından ve kompozit güvenirlik değerlerinden yararlanılmıştır. Bu kapsamda elde edilen bulgular alt başliklarda sunulmuştur.

İç tutarlılık güvenirliği. Ölçeğin güvenirliğini tespit etmede farklı yollar bulunmaktadır. Ölçeğin güvenirliği düşünüldüğünde en temel konulardan biri 
ölçeğin iç tutarlılı̆̆ıdır (Pallant, 2016). İç tutarlılık, belirli bir alanı ölçtüğü varsayılan maddelerin kendi aralarında homojen olup olmadığını, maddelerin istenen kavramı ne kadar ölçtüğünü belirlemede kullanılan bir ölçüttür (Karakoç ve Dönmez, 2014) ve iç tutarlılık tespitinde en yaygın Cronbach alpha katsayısı kullanılmaktadır (Pallant, 2016). Ölçümlerin iç tutarlılık güvenirliği için Cronbach alpha katsayısı incelenmiştir. Buna göre ölçeğin Cronbach Alpha katsayısı .92, birinci bileşenin Cronbach Alpha katsayıs1 .83, ikinci bileşenin Cronbach Alpha katsayısı .78, üçüncü bileşenin Cronbach Alpha katsayısı .79, dördüncü bileşenin Cronbach Alpha katsayısı .81 ve beşinci bileşenin Cronbach Alpha katsayısı .83 olarak hesaplanmıştır. Ayrıca Tablo 3'ten de görüleceği üzere maddelerin toplam puan korelasyonlarının .381 ile .668 arasında değiştiği ve tamamının .30 üzerinde olduğu tespit edilmiştir. Cronbach Alpha güvenirlik katsayısının .70 'in üzerinde ve madde toplam korelasyonun .30 ve daha yüksek olmasının yeterli olduğu (Büyüköztürk, 2011; Pallant, 2016; Tavşanc1l, 2014; Yaratan, 2017) göz önüne alındığında ölçümlerin güvenilir olduğu söylenebilir.

Yap1 güvenirliği (bileşik/kompozit güvenirlik-cr). Cronbach Alpha katsayısının madde sayısından etkilenmesi nedeniyle madde sayısının fazla olduğu durumlarda alfa katsayısına bir alternatif ve kontrol aracı olarak kompozit güvenirlik değerinden yararlanılmaktadır. Ölçeğin yapı güvenirliğinin sağlanabilmesi için CR değerinin .70'den büyük olması gerekmektedir (Fornell ve Larcker, 1981). Bu kapsamda da ölçeğin kompozit güvenirlik değerleri hesaplanmışır. Buna göre birinci bileşenin $C R$ değeri .80, ikinci bileşenin $C R$ değeri .86, üçüncü bileşenin $C R$ değeri .84, dördüncü bileşenin $\mathrm{CR}$ değeri .85 ve beşinci bileşenin $\mathrm{CR}$ değeri .87 olarak hesaplanmıştır. Ölçeğin toplamı için ise CR değeri .96 olarak bulunmuştur. Buna göre $\mathrm{CR}$ değerleri yapı güvenirliğinin sağlandığını kanıtlamaktadır.

\section{Tartışma, Sonuç ve Öneriler}

Etik ilkeler ve kodlar her örgüt için oldukça büyük bir öneme sahiptir. Bu ilkeler örgüt içerisinde personel alımından, finansal yönetime insan kaynaklarından eğitime kadar hemen her alanda karar verme sürecine yönelik çerçeveler sunmaktadır. Dolayısıyla bütün bu alanlarda doğru bir işleyiş sağlamak amaciyla örgütsel boyutta paydaşlar için etik ilkeler belirlenmiştir. Benzer bir çalışma üniversitelerdeki eğitim-öğretim sürecini daha iyi ve doğru şekilde yürütmek için de yapılmıştır. Bu kapsamda hem dünyada (Cambridge, 2011; Harvard, 2020) hem de Türkiye'de (YÖK, 2014) yükseköğretimde öğretim elemanları etik davranış ilkeleri belirlenmiştir. Ancak bu etik ilkelerin eğitim-öğretim sürecinde öğretim elemanları tarafından ne düzeyde uygulandığı önemli bir konudur. Çünkü etik olmak, sadece ilkeler koymayı değil, bu ilkeleri günlük hayatta davranış haline getirmeyi gerektirir. Alanyazın taramasında çeşitli yükseköğretim kurumlarının etik davranış ilkeleri olmasına rağmen öğretim elemanlarının bu ilkeleri hangi düzeyde sergilediğine ilişkin herhangi bir ölçme aracına rastlanmamıştır. Sadece ölçülebilen alanlarda ilerleme ve gelişme kaydedilebildiği de dikkate alındığında, yükseköğretimde eğitim-öğretim sürecinde öğretim elemanlarını etik açıdan değerlendirmeyi sağlayan bir ölçme aracına ihtiyaç duyulduğu açıktır.

Üniversite öğrencilerinin eğitim-öğretim etiğine ilişkin görüşlerini ifade eden geçerli ve güvenilir bir ölçme aracı geliştirmeyi amaçlayan bu çalışmada üniversite öğrencilerinden oluşan bir çalışma grubuyla geçerlilik ve güvenirlik analizleri yapılmıştır. Buna göre öncelikle alanyazın taraması yapılmış ve 51 maddeden oluşan 
bir taslak ölçek hazırlanmıştır. Hazırlanan taslak ölçek 319 üniversite öğrencisine uygulanmıştır. Ölçeğin yapısını ortaya koyabilmek için temel bileşenler analizine dayalı faktör analizi yapılmıştır. Faktör analizi ile ölçeğin tek faktörlü beş bileşenli bir yapı gösterdiği ortaya konulmuştur ve 24 maddeden oluşan ölçeğin açıkladığ1 toplam varyans yaklaşık \%60 olarak bulunmuştur. Scherer vd. (1988; akt. Tavşancıl, 2014) sosyal bilimlerdeki ölçeklerin açıkladığı varyans oranının en az \%40 olması gerektiğini belirtmektelerdir. Dolayısıyla Yükseköğretimde Eğitim-Öğretim Etiği Ölçeği Öğrenci Formu'nun açıkladığı varyansın yeterli olduğu kabul edilmiştir.

AFA ile faktör yapısı ortaya çıkarılan ölçeğin doğruluğunu sınamak için ikinci düzey DFA yapılmıştır. DFA için ölçek 315 üniversite öğrencisinden oluşan farklı bir çalışma grubuna yeniden uygulanmıştır. Analiz sonuçları ölçeğin kabul edilebilir uyum iyiliği indekslerine sahip olduğunu göstermiştir. Böylece ölçeğin geçerli olduğu kabul edilmiştir. Ölçeğin bileşenleri "Öğrencilere saygı gösterme", "Derse ilişkin bilgilendirme", "Öğrencilerin korunması", "Öğretim elemanımın yeterliliği" ve "Öğrencileri önemseme" olarak isimlendirilmiştir. Öğrencilere saygı gösterme bileşeninde faktör yük değerleri .472 ile .853 arasında değişmekte ve toplam varyansın \%35.79'unu açıklamaktadır. Derse ilişkin bilgilendirme bileşeninde faktör yük değerleri .700 ile .880 arasında değişmekte ve toplam varyansın \%8.21'ini açıklamaktadır. Öğrencilerin korunması bileşenindeki faktör yük değerleri .395 ile .800 arasında değişmekte ve toplam varyansın \%6.51'ini açıklamaktadır. Öğretim elemanının yeterliliği bileşeninde faktör yük değerleri .402 ile .820 arasında değişmekte ve toplam varyansın \%5.25'ini açıklamaktadır. Son bileşen Öğrencileri önemseme bileşeninde faktör yük değerleri .515 ile .758 arasında olup toplam varyansın \%4.29' unu açıklamaktadır. Açımlayıcı faktör analizi sonuçlarına göre Yükseköğretimde Eğitim-Öğretim Etiği Ölçeği Öğrenci Formu tek faktör ve beş bileşenli bir yapıyla \%60.04'lük bir varyansı açıklamaktadır.

Ölçeğin iç tutarlılık güvenirliği kapsaminda hesaplanan Cronbach Alpha katsayısına $(=.920)$ ve madde toplam korelasyonlarına göre ölçümlerin güvenilir olduğu kabul edilmiştir. Ölçeğin CR değerleri (birinci bileşen $=.80$, ikinci bileşen $=.86$, üçüncü bileşen $=.84$, dördüncü bileşen $=.85$, beşinci bileşen $=.87$ ve ölçek toplam $=.96$ ) yapı güvenirliği olduğunu göstermektedir. Likert tipi olarak geliştirilen ölçekte maddelerin ağırlık dereceleri Hiç katılmıyorum $=1$ ve Tamamen katılıyorum $=5$ olacak şekilde puanlandırılmıştır. Ölçekte ters puanlanan madde bulunmamaktadır. Elde edilen bulgular, geliştirilen ölçeğin yükseköğretimde eğitim öğretim etiğine yönelik öğrenci görüşlerini ölçmek için kullanılabilecek geçerli ve güvenilir bir araç olduğunu göstermektedir. Dolayısıyla bu ölçeğin, yükseköğretimde eğitim öğretim etiği ile ilgili araştırma yapmak isteyen araştırmacılar tarafından kullanilabileceği düşünülmektedir. Bu doğrultuda ölçekten alınabilecek toplam puan 24-120 arasındadır. Ölçekten alınan puanların 120 ve bu puana yakın olması ilgili ölçek maddeleri kapsamında öğrencilerin yükseköğretimde eğitim-öğretim etiğine ilişkin olumlu görüşlere sahip olduğu şeklinde ifade edilebilir. Ayrıca bu sonuç, öğretim elemanlarının öğrencilere karşı yükseköğretimde eğitim-öğretim etik ilkelerini gözeterek davrandığı şeklinde de yorumlanabilir.

Akademik alanda meslek etiği genellikle eğitim-öğretimde, araştırmada ve topluma hizmet kapsamında üç boyut altında incelenmektedir. Bu araştırmada eğitimöğretim alanındaki etik faaliyetlere odaklanılmıştır. Dolayısıyla ileriki çalışmalarda akademisyenlerin araştırma ve topluma hizmet faaliyetlerindeki etik veya etik diş1 davranışlarına yönelik ölçekler de geliştirilebilir. Bu ölçek üniversitelerin lisans 
programı öğrencileri için geliştirilmiştir. Bu sebeple araştırmacılar önlisans ve lisansüstü öğrenciler için de geçerlik ve güvenirlik çalışmaları yaparak bu öğrencilerin yükseköğretimde eğitim-öğretim etiğine ilişkin görüşlerini belirleyebilir. Ayrıca etik alg1sı öğrencilerin üniversiteye bağlılığından, memnuniyet düzeylerine kadar çeşitli değişkenleri etkileyebilir. Bu doğrultuda nicel araştırmalar için bu ölçek üniversite öğrencilerinin bağlılık, kalite, memnuniyet algılarını yordamak amacıyla da kullanılabilir.

\section{Kaynakça}

Akçamete, G., Kayhan, N., and Yıldırım, A. E. S. (2017). Scale of professional ethics for individuals working in the field of special education: Validity and reliability study. Cypriot Journal of Educational Science, 12(4), 202-217.

Arslan, M. (2014). Felsefeye giriş (21. Baskı). Ankara: Adres Yayınları.

Ay, F. (2017). Öğretim üyesinin etik sorumluluğu. Să̆lık Bilimleri Dergisi, 4(3), 267-271. 10.17681/hsp.281915

Aydın, İ. (2006). Ĕğitim ve öğretimde etik (2. Baskı).Ankara: Pegem Akademi.

Aydın, İ. (2016). Akademik etik (1. Bask1).Ankara: Pegem Akademi.

Aypay, A. (2006). Üniversitelerde akademik etkinlik ve örgütsel davranış arasındaki ilişki. Kuram ve Uygulamada Ĕ̆itim Yönetimi, 46(46), 175-198.

Balcı, A. (2015). Sosyal bilimlerde araştırma yöntem, teknik ve ilkeler (15. Baskı). Ankara: Pegem Akademi.

Blevins-Knabe, B. (1992). The ethics of dual relationships in higher education. EthicsandBehavior, 2(3), 151-163. doi.org/10.1207/s15327019eb0203_2

Brown, R.D., and Krager, L. (1985). Ethical issues in graduate education: Faculty and student responsibilities. The Journal of Higher Education, 56(4), 403-418. doi.org/10.2307/1981303

Burakgazi-Gelmez, S. ve Can, İ. (2018). Development and validation of a professional ethics scale for pre-service teachers. Uluslararası Ĕ̆itim Programları ve Öğretim Çalışmaları Dergisi, 8(2), 275-298. doi.org/10.31704/ijocis.2018.013

Büyüköztürk, Ş. (2002). Faktör analizi: Temel kavramlar ve ölçek geliştirmede kullanımı. Kuram ve Uygulamada Eğitim Yönetimi Dergisi, 8(4), 470-483.

Büyüköztürk, Ş. (2011). Sosyal bilimler için veri analizi el kitabı (15. Bask1). Ankara: Pegem Akademi.

Cambridge Üniversitesi. (2011). Etik Kurallar (Code of ethical conduct). https://www.cambridgecollege.edu/code-ethical-conduct (Erişim Tarihi: 17.10.2020).

Cevizci, A. (2002). Etiğe giriş. İstanbul: Engin Yayıncılık.

Cevizci, A. (2016). Uygulamalı etik (2. bask1). Ankara: Say Yayınları.

Cevizci, A. (2019). Eğitim felsefesi (7. baskı). Ankara: Say Yayınları.

Clevenger, M.R. (2019). Corporate citizenship and higher education. Palgrave Macmillan.

Çokluk, Ö., Şekercioğlu, G. ve Büyüköztürk, Ş. (2012). Sosyal bilimler için çok değişkenli istatistik SPSS ve LISREL uygulamalarn (2 . Baskı). Ankara: Pegem Akademi.

Erdem, F., Ömüriş, E., Özlem, Ö. Z., Hüseyin, B. O. Z., Özmen, M. ve Kubat, U. (2014). Öğretim elemanlarının etik sorumlulukları üzerine üniversite öğrencilerinin alg1lamaları. Ĕ̆itimde Nitel Araştırmalar Dergisi, 2(1), 38-63. 10.14689/issn.21482624.1.2s $2 \mathrm{~m}$

Erkuş, A. (2019). Psikolojide ölçme ve ölçek geliştirme-I. Ankara: Pegem Akademi. 
Fornell, C., and Larcker, D. F., (1981). Evaluating structural equation models with unobservable variables and measurement error. Journal of Marketing Research, 18(1), 39-50. doi.org/10.2307/3151312

Gedik Dinç, R. ve Gizir, S. (2019). Öğrencilerin bakış açısından öğretim elemanlarının sınıf içindeki etik dişı davranışları. Yükseköğretim Dergisi, 9(1), 29-39. doi.org/10.2399/yod.18.033

Gençoğlu, M. (2015). Öğretim elemanlarının akademik etik kapsamındaki davranışlarına ilişkin öğretmen adaylarının görüşleri (Yayınlanmamış yüksek lisans tezi). Girne Amerikan Üniversitesi, Kuzey Kıbrıs Türk Cumhuriyeti.

Gürbüz, S. ve Şahin, F. (2017). Sosyal bilimlerde araştırma yöntemleri. Ankara: Seçkin Yayincilik.

Haider, S. Z., Munawar, U., and Ali, R. (2020). Introduction and validation of Ethics Practices Scale (EPS) and its application in Pakistani Higher Education. SJESR, 3(2), 121-131. 10.36902/sjesr-vol3-iss2-2020(121-131)

Harvard Üniversitesi. (2020). Etik kurallar (codes of conduct). https://gsas.harvard.edu/codes-conduct (Erişim Tarihi: 17.10.2020)

Haynes, F. (2002). Eğitimde etik. İstanbul: Ayrıntı Yayınları

Heyneman, S. (2011). The corruption of ethics in higher education. International Higher Education, 62, 8-14. doi.org/10.6017/ihe.2011.62.8530

Hinkin, T.R. (1995). A review of scale development practices in the study of organizations. Journal of Management, 21(5), 967-988. doi.org/10.1016/01492063(95)90050-0

Karakoç, F.Y. ve Dönmez, L. (2014). Ölçek geliştirme çalışmalarında temel ilkeler. Tıp Eğitimi Dünyası, (40), 39-49. doi.org/10.25282/ted.228738

Keith-Spiegel, P., Whitley, B.E., Balogh, D.W., Perkins, D.V., and Wittig, A.F. (2002). The ethics of teaching: A casebook (2nd edition). Lawrence Erlbaum Associates.

Kline, R. B. (2005). Principles and practice of structural equation modeling (2nd ed.). New York: Guilford Press.

Kuther, T. L. (2003). A profile of the ethical professor: Student views. College teaching, 51(4), 153-160. doi.org/10.1080/87567550309596431

Lynn, M.R. (1986). Determination and quantificationof content validity. Nursing Research, 35, 382-385. doi.org/10.1097/00006199-198611000-00017

Macfarlane, B. (2004). Teaching with integrity: The ethics of higher education practice. NewYork: Routledgefalmer Press.

Morgado, F.F.R., Meireles, J.F.F., Neves, C.M., Amaral, A.C.S., and Ferreira, M.E.C. (2017). Scale development: Ten main limitations and recommendations to improve future research practices. Psicologia: Reflexão e Crítica, 30(3). 10.1186/s41155-016-0057-1

Morgan, B. L., and Korschgen, A. J. (2001). The ethics of faculty behavior: Students' and professors' views. College Student Journal, 35(3), 418-432.

Murray, H., Gillese, E., Lennon, M., Mercer, P., and Robinson, M. (1996). Ethical principles for college and university teaching. New Directions for Teaching and Learning, 66, 57-63. doi.org/10.1002/tl.37219966611

Özcan, K. ve Balyer, A. (2012). Öğretim elemanları etik davranışları ölçeğinin Türkçeye uyarlanması. Adıyaman Üniversitesi Sosyal Bilimler Enstitüsü Dergisi, (10), 345376. doi.org/10.14520/adyusbd.411 
Pallant, J. (2016). SPSS kullanma kılavuzu SPSS ile adım adım veri analizi (S. Balc1 ve B. Ahi, Çev.). Ankara: Anı Yayıncılık.

Patton, M. Q. (2014). Nitel araştırma ve değerlendirme yöntemleri (M. Bütün ve S. B. Demir, Çev. Ed.). Ankara: Pegem Akademi.

Polit, D. F., and Beck, C. T. (2006). The Content Validity Index: Are you sure you know what's being reported? Critique and recommendations. Research in Nursing and Health, 29, 489-497. 10.1002/nur.20147

Revell, L., and Arthur, J. (2007) Character education in schools and the education of teachers. Journal of Moral Education, 36(1), 79-92. https:// doi.org/10.1080/03057240701194738

Schnake, M., Fredenberger, W., and Dumler, M. P. (2004). Dimensions of student perceptions of faculty ethical behevior: Refining a measure and reletionships with selected outcome variables. Academy of Educational Leadership Journal, 8(2), 1-16.

Schermelleh-Engel, K., Moosbrugger, H. and Müller, H. (2003). Evaluating the fit of structural equation models: Tests of significance and descriptive goodness-offit measures. Methods of Psychological Research Online, 8(2), 23-74.

Simon D., Kriston L., Loh A., Spies C., Scheibler F., Wills C., and Harter M. (2010). Confirmatory factor analysis and recommendations for improvement of the Autonomy-Preference-Index (API). Health Expectations, 13, 234-243. doi.org/10.1111/j.1369-7625.2009.00584.x

Strike, K.A., and Soltis, J.F. (2009). The ethics of teaching (Fifth Edition). Teachers College, Columbia University.

Sümer, N. (2000). Yapısal eşitlik modelleri: Temel kavramlar ve örnek uygulamalar. Türk Psikoloji Yazıları, 3(6), 49-74.

Tabachnick, B. G., and Fidell, L. S. (2014). Using multivariate statistics. New York, USA: Harper Collins College Publishers.

Tan, Ş. (2016). SPSS ve excel uygulamal temel istatistik-I. Ankara: Pegem Akademi.

Tavşanc1l, E. (2014). Tutumların ölçülmesi ve SPSS ile veri analizi (4. Bask1). Ankara: Nobel Yayın Dağıtım.

Yaratan, H. (2017). Sosyal bilimler için temel istatistik SPSS uygulamalı. Ankara: Anı Yayıncilik.

Yılmaz, F. ve Ünsar, A. S. (2019). Öğretim elemanlarının etik değerlerinin belirlenmesine yönelik öğrenci algısı. Adıyaman Üniversitesi Sosyal Bilimler Enstitüsü Dergisi, (33), 105-124. doi.org/10.14520/adyusbd.472204

YÖK. (2014). Yükseköğretim kurumları etik davranış ilkeleri. Ankara: YÖK Yayınları.

Yurdabakan, İ. ve Çüm, S. (2017). Scale development in behavioral sciences (Based on exploratory factor analysis). Turkish Journal of Family Medicine and Primary Care Electronic Journal, 11(2), 108-126. doi.org/10.21763/tjfmpc.317880

Zhu, Y. Y., and Guo, M. Y. (2021). Influence of differential leadership on teachers' professional ethics: An empirical study from Chinese universities. Asia Pacific Education Review, 22(3), 549-564. 


\section{Summary}

\section{Introduction}

Universities are obliged to develop their students in terms of moral and social aspects as well as academic development. This responsibility largely falls on the lecturers, who constantly interact with the students in the education process. For this reason, it is important for lecturers to behave in accordance with ethical principles in the education process. Because adult students at higher education level can create their own professional values based on the behaviors they are exposed to during this process. For this reason, as much as what the lecturers teach and how they teach, how they carry out this process towards all students is taken into account.

Ethics is an important issue for higher education institutions in both international and national frameworks. In this direction, universities (Cambridge University, 2011; Harvard University, 2020; YÖK, 2014) have determined a code of ethical conduct that guides stakeholders in order to carry out the education process in a healthy and correct manner. However, no data collection tool has been found to measure the level of fulfillment of these principles by lecturers. In this research, it is aimed to develop a valid and reliable scale that determines the opinions of students on ethics at higher education.

\section{Method}

In this study, quantitative research methods and factor analysis technique are used. Ethics in Education at Higher Education Scale-Student Form is developed in several phases. This process starts with the need analysis and continues with composing the item pool based on literature review, pilot study, analysis, and finalization of the scale.

This scale development study is carried out with two different study groups. Participants are selected with criterion sampling technique, which is one of the purposeful sampling methods (Patton, 2014). The first study group consists of 319 undergraduate students. The data is collected from 3rd and 4th class undergraduate students at the state universities' faculty of education in Turkey. The first study group is used for exploratory factor analysis (EFA). The second study group is composed of 315 undergraduate students who continue their studies at the faculty of education of state universities in Turkey. This study group is used for confirmatory factor analysis (CFA). In this process, EFA is performed with the SPSS program. Afterwards, the CFA of the scale is done in the AMOS program.

\section{Results}

Ethics in Education at Higher Education Scale-Student Form consists of 24 items under a single-factor structure and five components including respecting students, informing about courses, protecting students, proficiency of lecturers, caring for students. Factor loads of the items of respecting students component (five items) are between .472 and .853 , and it explains $35.79 \%$ of the total variance. The factor loads of the items of the second component (three items) changes from .700 to .880, and it explains $8.21 \%$ of the total variance. The factor loads of the items of the protecting students component (six items) are calculated as between .395 and .800, and it explains $6.51 \%$ of the total variance. The factor loads of the items of the fourth component (five items) are between .402 and .820 , and it explains $5.25 \%$ of the total variance. The factor loads of 
the items of the caring for students component (five items) are between .515 and .758 , and it explains $4.29 \%$ of the total variance.

The total variance explained by a single-factor structure and five components is $60.04 \%$. It is seen that all the item total score correlations are higher than $0.30(0.381-$ $0.668)$. What's more, there is a positive $(.52-.83)$ and significant $(p<0.01)$ relationship between the components, both within themselves and with the total score. The relationship of each component with the total score is higher than the relationship (.60.83) with the other components. This shows that the scale is single-factor, but multicomponent. The total Cronbach Alpha reliability coefficient of this scale is 0.92. After EFA analysis, to confirm the scale structure, CFA analysis is conducted. The calculated $\chi^{2} / \mathrm{df}$ ratio of this scale is shown as $1.87\left(\chi^{2} / \mathrm{df} \leq 3.00\right)$ and RMSEA value is 0.05 (RMSEA $\leq 0.05)$. Other fit indices are determined as $\mathrm{NFI}=.89, \mathrm{CFI}=.94, \mathrm{GFI}=.89$, $\mathrm{AGFI}=.86, \mathrm{CR}=.96$. Accordingly, it is possible to say that as a result of CFA testing, the one-factor model of the Ethics in Education at Higher Education Scale-Student Form is confirmed.

\section{Discussion}

In this study, Ethics in Higher Education Scale-Student Form is developed and validity-reliability studies are conducted. As a result of the validity and reliability analysis, it is determined that the Ethics in Education at Higher Education ScaleStudent Form consists of 24 items under a single-factor structure and five components. These include respecting students, informing about courses, protecting students, proficiency of lecturers, caring for students. This structure, which is determined as a result of EFA, explains $60.04 \%$ of the total variance. Moreover, there is a positive and significant relationship between the components, both within themselves and with the total score (.60-.83). This has pointed out that the structure of the scale comprises a single-factor and multi-component.

Model fit of a single-factor and multi-component structure determined by EFA is tested with CFA over the second study group. Accordingly, the model fit indices of the scale $(\chi 2 / \mathrm{df}=1.87, \mathrm{RMSEA}=0.05, \mathrm{NFI}=.89, \mathrm{CFI}=.94, \mathrm{GFI}=.89, \mathrm{AGFI}=.86)$ are examined. Fit indices of the measurement model show that the scale has good fit (Simon et al., 2010). It is seen that the measurement model of this scale has acceptable goodness of fit. In this scale, weights of the items are scored between 1 point (totally disagree) and 5 points (totally agree). Accordingly, the total score that can be obtained from the scale is between 24 and 120. It can be stated that the scores, which are close to 120, point out that according to the students' perceptions, lecturers have fulfilled their responsibilities in the context of ethics in higher education.

\section{Araştırmanın Etik İzinleri}

Yapılan bu çalışmada “Yükseköğretim Kurumları Bilimsel Araştırma ve Yayın Etiği Yönergesi" kapsamında uyulması belirtilen tüm kurallara uyulmuştur. Yönergenin ikinci bölümü olan “Bilimsel Araştırma ve Yayın Etiğine Aykırı Eylemler” başlı̆̆ı altında belirtilen eylemlerden hiçbiri gerçekleştirilmemiştir.

Etik kurul izin bilgileri

Etik değerlendirmeyi yapan kurul ad1= Trakya Üniversitesi Sosyal ve Beşeri Bilimler Etik Kurulu

Etik değerlendirme kararının tarihi= 06.05.2020 
Etik değerlendirme belgesi sayı numarası=29563864-050.04.04-E.432843

\section{Authors' Biodata/ Yazar Bilgileri}

Özge ERDEMLİ Ankara Üniversitesi Eğitim Bilimleri Fakültesi Eğitim Bilimleri Bölümü, Eğitim Yönetimi Anabilim Dalı'nda araştırma görevlisi olarak görev yapmaktadır. Aynı zamanda Ankara Üniversitesi Eğitim Bilimleri Bölümü'nde doktora öğrencisidir. Araştırma alanı eğitim yönetimi, okul yönetimi, öğretmenin mesleki gelişimi, eğitim liderliği ve eğitimde etik üzerinedir. Ayrıca bu alanlarda ulusal ve uluslararası bilimsel çalışmaları bulunmaktadır.

Özge Erdemli is a research assistant Ankara University, Faculty of Educational Sciences, at the Department of Educational Administration. Also she is a PhD student at the department of educational sciences at Ankara University. Her research interests include educational administration, school management, teacher professional development, educational leadership, ethics in education. In addition, she has national and international scientific studies in these fields.

Tuğba GÜNER DEMİR Ankara Üniversitesi Eğitim Bilimleri Fakültesi Eğitim Bilimleri Bölümü, Eğitim Yönetimi Anabilim Dalı'nda araştırma görevlisi olarak görev yapmaktadır. Aynı zamanda Ankara Üniversitesi Eğitim Bilimleri Bölümü'nde doktora öğrencisidir. Araştırma alanı eğitim yönetimi, okul yönetimi, öğretmenin mesleki gelişimi, eğitim liderliği ve eğitimde etik üzerinedir. Ayrıca bu alanlarda ulusal ve uluslararası bilimsel çalışmaları bulunmaktadır.

Tuğba Güner Demir is a research assistant Ankara University, Faculty of Educational Sciences, at the Department of Educational Administration. Also she is a PhD student at the department of educational sciences at Ankara University. Her research interests include educational administration, school management, teacher professional development, educational leadership, ethics in education. In addition, she has national and international scientific studies in these fields.

Gül KURUM Trakya Üniversitesi Eğitim Fakültesi Eğitim Yönetimi Bölümü'nde araştırma görevlisi olarak görev yapmaktadır. Doktora derecesini 2019 yılında Ankara Üniversitesi Eğitim Bilimleri Fakültesi'nden almıştır. 2017 yılında Dublin Şehir Üniversitesi'nde Değerlendirme ve Kalite Merkezi'nde misafir araştırmacı olarak bulunmuştur. Lisans düzeyinde Eğitim Yönetimi, Türk Eğitim Sistemi ve Okul Yönetimi, Sınıf Yönetimi, Eğitimde Ahlak ve Etik, Karşılaştırma Eğitim derslerini yürütmektedir. Araştırma alanı okul yönetimi, eğitim liderliği, okul değerlendirme, okul öz-değerlendirme üzerinedir. Ayrıca bu alanlarda ulusal ve uluslararası bilimsel çalışmaları bulunmaktadır.

Gül Kurum is a research assistant at the Faculty of Education, Department of Educational Administration at Trakya University, Edirne-Turkey. She earned her PhD from the School of Educational Sciences at Ankara University in 2019. As a visiting researcher she was at Evaluation and Quality Centre, Dublin City University, Dublin, Ireland in 2017. She is teaching Educational Administration, Turkish Education 
System and School Management, Classroom Management, Ethics in Education Comparative Education in undergraduate levels. Her research area is about school management, educational leadership, school evaluation, school self-evaluation. In addition, she has national and international scientific studies in these fields. 